\title{
Recovery and flow in cave mining: current knowledge gaps and the role of technology in the future
}

\author{
AD Campbell Beck Engineering, Australia
}

\begin{abstract}
Gravity flow of granular material in a caving mine is complex. Ore recovery and cave flow is impacted by wide particle size distributions, particle interlocking, an evolving cave geometry, and the mine draw strategy. However, these factors are rarely quantified in forecasts of cave performance at key stages in the planning process. Reliable tools for simulating cave flow and the technology to measure cave flow and footprint deformation have only emerged in the last 10 years. This includes technology such as electronic cave markers and tracker systems, 3D laser scanning for tunnel deformation and fragmentation measurement as well as coupled cave flow-deformation numerical simulations.

This paper provides an overview of how the current state of cave flow knowledge has evolved and the knowledge gaps that still exist. The impact of these knowledge gaps is described in context with mine design and current design guidelines. A series of experiments to address these knowledge gaps have been conceptualised for future trials in existing and future caving mines. A methodology including instrumentation, monitoring requirements and operational practices is outlined for each experiment.
\end{abstract}

Keywords: block caving, sublevel caving, granular flow, fragmentation

\section{Introduction}

Material flow in caving mines is arguably one of the most complex phenomena in rock mechanics. Highly variable particle sizes, particle interlocking, fines migration, internal rilling and communition occur at multiple length scales, and change dynamically throughout the muckpile as the cave is drawn. The added influence of cave propagation and operational loading practices results in a highly complex physical system. Granular flow in caving mines has been studied extensively since the early 1960s. Early scale model experiments provided researchers with a general understanding of cave flow which corresponded well with field observations. The measurements of these models have become increasingly questioned by modern practitioners as the scale of caving operations increases. Measurements in existing caving mines using newly developed cave flow and fragmentation measurement techniques have been challenging established theory and design methodologies, but additional measurement is required. More recent 'disturbed flow' theory is yet to be measured or quantified in detail. As a result, the cave mining community continues to rely on empirical design guidelines and idealised flow theory developed from scaled physical models.

Caving guidelines developed in the 1980s and 1990s using sand models continue to be used today. Reliance on these empirical rules and guidelines remains controversial, however, they continue to be used largely because more reliable data is not available to update existing mine design guidelines or validate numerical flow simulations. The need for additional measurement is becoming increasingly important as caving mines become larger and increase to a scale beyond the limits of which physical model can replicate full-scale cave behaviour. The increases in mining dimensions are also approaching the upper limit of existing design guidelines. The impact of mine design for both stability and ore recovery are becoming increasingly important for the viability of future caving mines, which are becoming deeper and target lower ore grades.

The reason so many unknowns still exist is because measurement in the field is difficult, expensive, time-consuming and because the technology and monitoring systems required simply did not exist in the past. This has changed. Technological developments in the past 10 years include electronic markers, cave 
beacons, low cost laser scanning, and significant advances in software and computing. Recent technological advances provide solutions to overcoming some of the previous barriers.

Various numerical techniques for simulating cave flow and ore recovery have been developed and continue to evolve as computing power increases. Unfortunately, limited field measurements have prevented these models from being validated. Many flow simulation tools still rely on calibration using data from scaled physical experiments that have multiple similitude related issues.

This paper discusses the role of technology in the development of existing flow theory, including small-scale physical experiments, field measurements in operating mines and numerical simulation. The evolution of caving knowledge, with respect to key experiments and the current understanding of cave flow, is provided. The mine design problem in terms of recovery and stability is discussed, including the limitations of existing design guidelines and implications of unquantified cave flow behaviour that can influence the performance of caving mines.

A combination of field experiments and modern technology will be critical for addressing current unknowns. Recently developed technology is discussed in the context of field trials and applications to address existing unknowns, calibrate numerical models and update existing design guidelines. Future full-scale trials and conceptual experimental designs are also provided to guide future trials.

\section{Current state of knowledge}

Scaled physical models using sand and gravel, full-scale experiments in operating mines, and various numerical simulations, have provided insight to the complex mechanisms that occur in caving mines. However, recent measurements in operating mines using newly available measurement devices now challenge existing flow theory. This section of the paper outlines the development of the current state of cave flow knowledge, from early physical models to recent field measurements in operating mines and the use of numerical simulation.

\subsection{Physical models}

The earliest physical models used to simulate flow in sublevel caving (SLC) mines were adopted from studies in bins and hoppers (Kvapil 1965). These scaled models generally consisted of a wooden or metal box with a Perspex front and an outlet at the bottom for drawing out the sand that filled the model. As the granular material was drawn from the outlet at the bottom of the model, the flow patterns in the coloured layers of sand could be visualised (Figure 1). Early practitioners were mostly interested in SLC rather than block caving due to the operations in which they worked. These mines included the Swedish iron ore mines (Caspar 1960; Janelid \& Kvapil 1966), Mufulira in Zambia (Airey 1965; Cox 1969), Craigmont Mines in Canada (Sandstrom 1972), and Mount Isa Mines in Australia (Panczakiewicz 1977; Just 1981). Physical models were used to quantify the effect of different material properties including particle size, angularity, density and compaction. Design variables such as drawpoint spacing, drawpoint width and draw control practices were tested and correlations and mathematical relationships established. Over time, physical models became larger in size to improve similitude to full-scale mining conditions (Peters 1984; Power 2004). Some of the key research developments are summarised here. A more extensive synopsis is provided in Campbell (2019). 

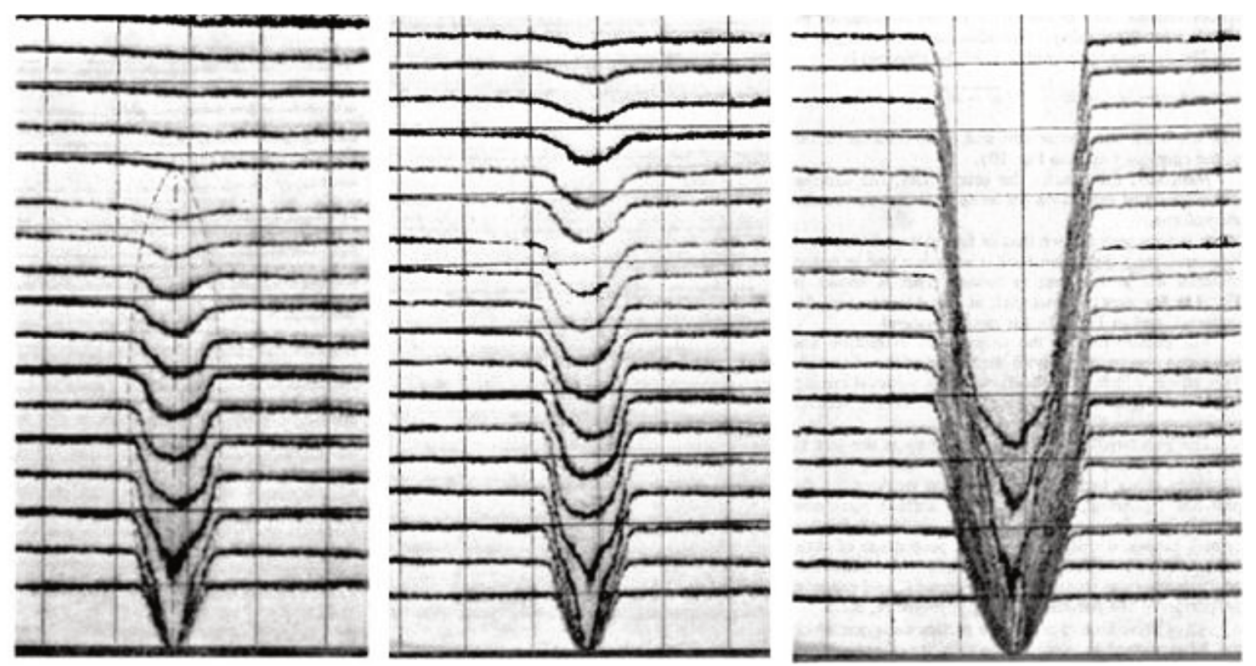

Figure 1 Kvapil's sand model (Kvapil 1965)

Material extraction in early sand models resulted in a series of growing ellipsoids, which became known as ellipsoid theory (Kvapil 1965; Janelid \& Kvapil 1966) (Figure 1). The width of the ellipsoid was found to be influenced by the particle size and particle size distribution (Caspar 1960; Kvapil 1965; Gardner 1966; McCormick 1968; Free 1970). The relative flow rate of different sized particles and rapid migration of smaller particles (fines) was first described by Redaelli (1963), and again by Janelid \& Kvapil (1966). This would become known as fines migration in modern caving.

Key components of cave flow were identified by Kvapil (1965). These regions were related to material extraction and movement and are illustrated in Figure 2. The movement zone is defined as the outer limit of material that has moved during material draw, but not necessarily been recovered through the drawpoint. The extraction zone is the boundary outlining the original position of material that has been recovered through a drawpoint. The drawzone or draw cone is the shape formed by higher velocity material within the movement zone.

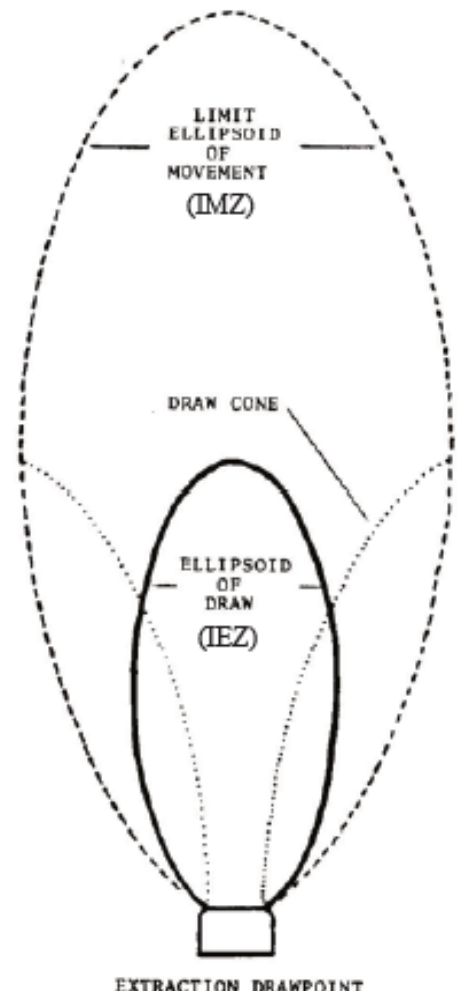

Figure 2 The isolated extraction zone (IEZ) and isolated movement zone (IMZ) (Just 1981) 
Airey (1965) was the first to describe the movement zone and the stagnant zone between multiple outlets (or drawpoints) in scale models. This was the first recording of what would later become known as isolated draw. In the case of isolated draw, the movement zone and extraction zone are referred to as the isolated movement zone and the isolated extraction zone, respectively.

McCormick (1968) found that for high material draw, the extraction zone was near vertical and almost cylindrical in shape, except for the cone at the bottom near the drawpoint. McCormick (1968) found that wider outlets resulted in wider extraction zones in the near-field close to the drawpoint and had a marginal effect on the width of the extraction zone higher in the drawzone. The experiments also revealed that angular particles were found be more prone to hang-ups compared to rounded material.

The first 3D physical models to simulate draw in a block cave environment were undertaken at the Shabanie Mine in the late 1970s and published by Marano (1980) and Heslop \& Laubscher (1981). The experiments found that models with multiple openings that were sufficiently close together with interacting draw zones produced different flow patterns compared with single isolated draw zones for widely spaced openings. The overlapping draw zones measured by Marano (1980) later became known as interactive draw (Heslop \& Laubscher 1981; Laubscher 1994). Interactive draw was theorised to improve recovery in both block cave and SLC mines if the drawpoints were spaced sufficiently close together. Similar to previous research, the width of the isolated draw zones was determined by the fragmentation size (Laubscher 1994). Based on experimental data from the sand models, draw interaction was forecast to occur if the drawpoints were spaced closer than 1.5 times the width of the isolated drawzone. The sand model results were scaled up to provide guidelines for drawpoint spacing based on forecast fragmentation (Figure 3). Results of the sand models were compared to underground drawpoint observations. The mine used a $10 \mathrm{~m}$ drawpoint spacing and a flat undercut (or flat top of the drawbell apex) which differs significantly from modern block caves. Additional guidelines based on the percentage of fragmentation greater than $2 \mathrm{~m}^{3}$ were also incorporated into design charts provided exclusively to the sponsors of the International Caving Study. These charts cannot be provided here; however, the premise of drawpoint spacing to achieve interactive draw is consistent with Figure 3.

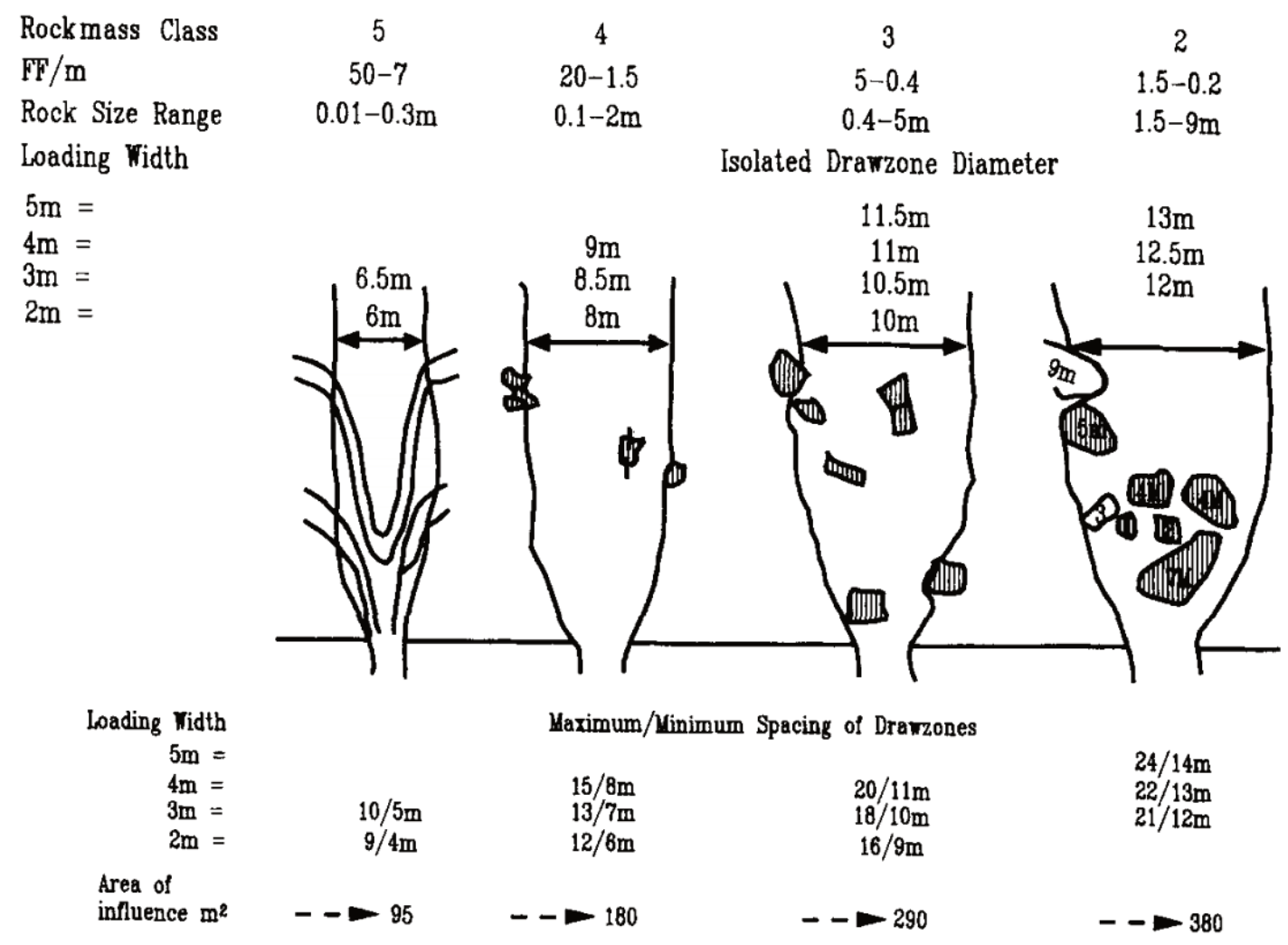

Figure 3 Maximum/minimum spacing of drawzones based on isolated drawzone diameter (after Laubscher 1994) 
Laubscher (1994) identified potential problems with the sand models used to establish the interactive flow theory and drawpoint spacing guideline. He questioned the use of the results from the sand models and the application in full scale, stating:

"The question is whether the interactive theory based on isolated draw zones can be wholly applied to coarse material, where arch spans of $20 \mathrm{~m}$ have been observed. The collapse of large arches will affect the large area overlying the drawpoint" and "The formation of large arches lead to wide draw zones in the coarse material, so the drawzone spacing can be increased". Laubscher (1994)

A number of shortcomings in the method used to develop the interactive draw theory are described by Castro (2006) and Halim (2006). Arancibia et al. (2008) notes that extraction level layout design has not evolved beyond the methodologies proposed by Laubscher, despite the increasing scale of cave mine layouts and loading equipment. However, the Laubscher guideline (1994 and 2000) remains in use and has been republished in textbooks, including Brown (2007) and Laubscher et al. (2017).

Drawzones in operating mines were also hypothesised to widen at increasing height due to failure of the pillars of broken material between the isolated draw zones, resulting in draw interaction high in the muckpile (Laubscher 2000). The interaction of draw zones as material was extracted uniformly from the drawpoints in the model was found to result in even lowering of the sand and markers at the top of the model (Figure 4). This cave flow behaviour would become known as mass flow. The height at which the interacting movements zones, with higher velocity drawdown direction above the drawpoints, transitions to mass flow is described as the height of interaction.

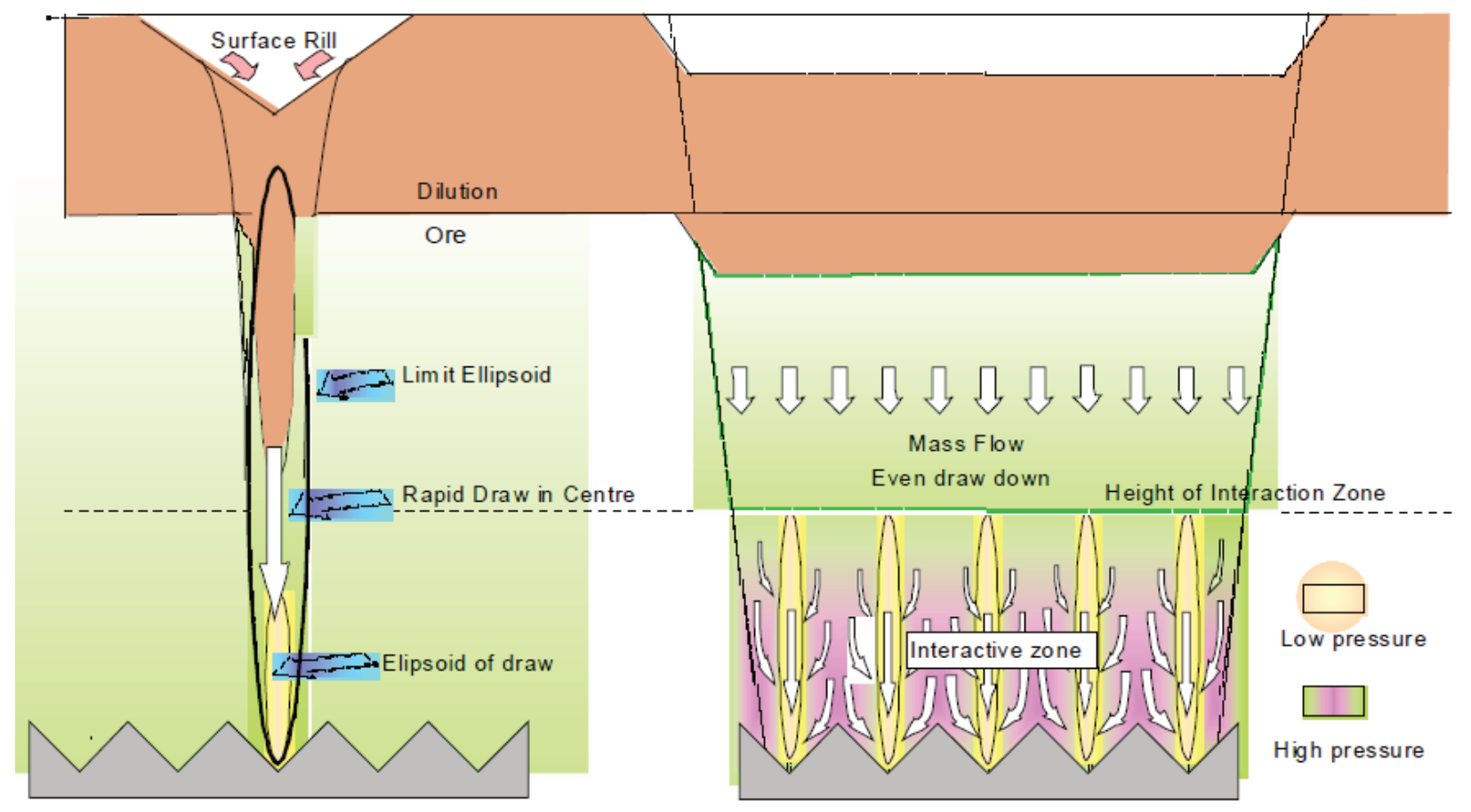

(a)

(b)

Figure 4 (a) Effect of drawing a single drawpoint; and (b) Drawing multiple drawpoints simultaneously (after Laubscher 2000)

Power (2004) used the largest 3D physical model ever built to clarify the effect of particle size distribution on drawzone geometry (Figure 5). The experiments confirmed that particle size affects the height and width of the drawzone and the magnitude of the effect was greater than previous estimates (Power 2004). Power (2004) also confirmed that ellipsoid theory is an adequate model for characterisation of the extraction zone when the draw geometry can be linked to the effect of particle size. Experimental testing by Castro et al. 
(2007) using the same physical model as Power (2004) demonstrated that interactive draw zones required a much closer drawpoint spacing than proposed by Laubscher (1994).

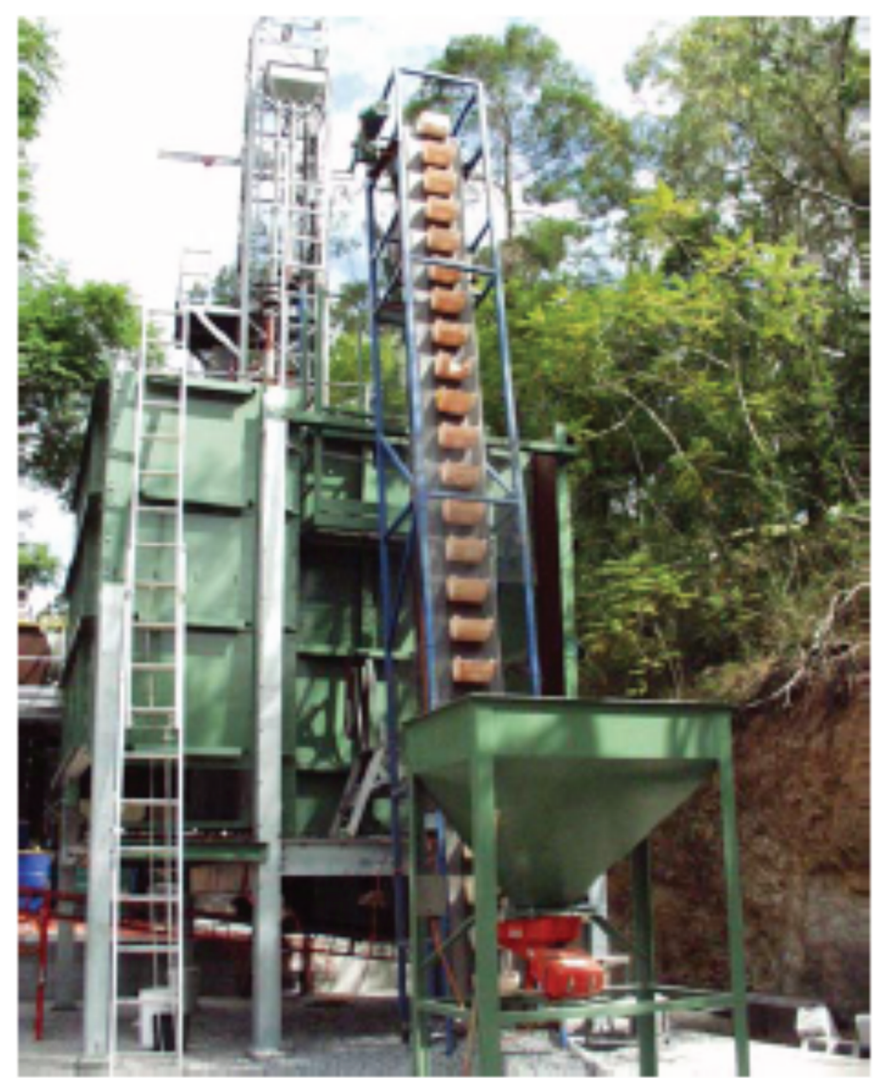

Figure 5 Large-scale 3D physical model used by Power (2004)

The impact of large rocks causing blockages and hang-ups in drawpoints in operating mines is well known. Scale models have been used to simulate the impacts of large rocks and disruption to uniform flow typically observed in sand and gravel experiments. Stazhevskii (1996) used larger rocks in model experiments to measure the effect on flow behaviour and how the presence of oversize in operating mines can result in disturbed flow conditions. An example from the experiment is shown in Figure 6. Heslop \& Laubscher (1981) also previously noted that large rocks can distort and destroy flow ellipsoids in scale models. Due to the large variation of fragmentation in operating mines, Stazhevskii (1996) concluded that flow patterns observed in early scale models were not likely to occur in an operating mine environment.

Large particles, or groups of interlocking particles, were shown to cause disturbed flow conditions in physical and numerical models conducted by Sharrock \& Hashim (2009) (Figure 7). Sharrock \& Hashim (2009) also proposed three types of flow disturbance. Static disturbance occurs when a large particle is clamped in place, causing the formation of new flow paths. Kinematic disturbance is due to the difference in flow velocity of particles of different size (i.e. fines migration). The third mechanism is a combination of static and kinematic disturbance occurring at the same time. The impact of the disturbed flow on the size and shape of extraction and movement zones could not be quantified by Sharrock \& Hashim (2009), though it was suggested to be significant and greater than the effect of particle size and shape. 


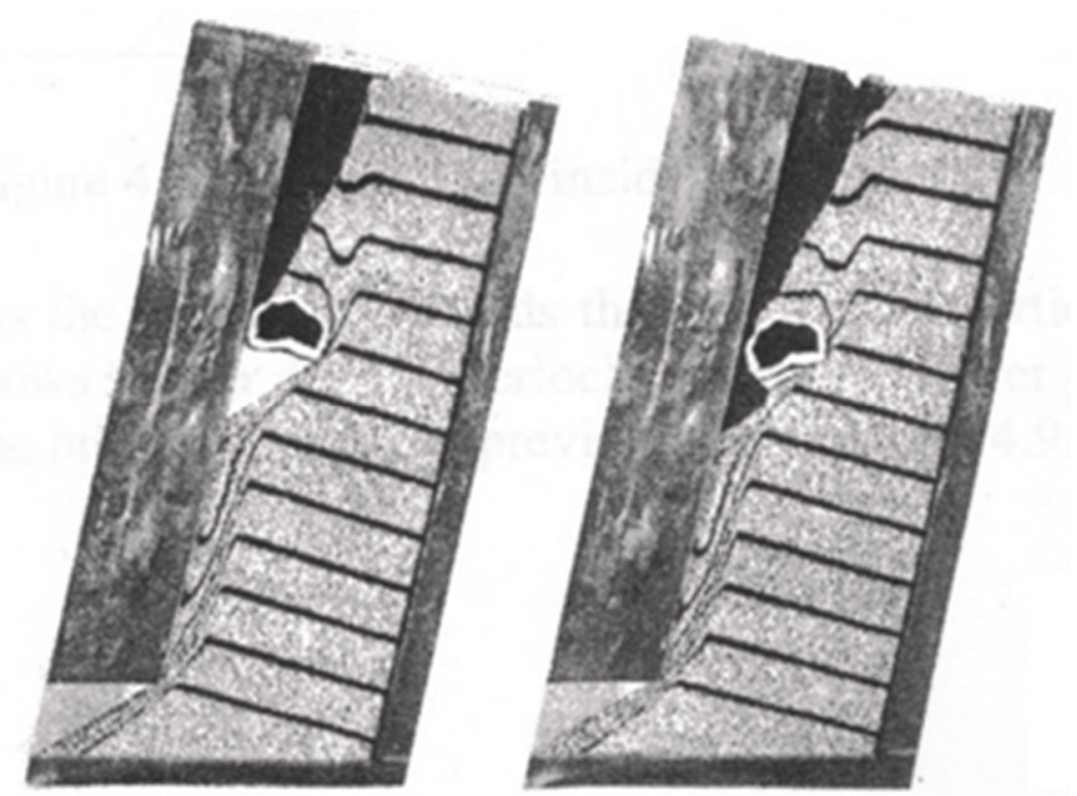

Figure 6 Disturbed flow caused by a large block in a scale model (Stazhevskii 1996)

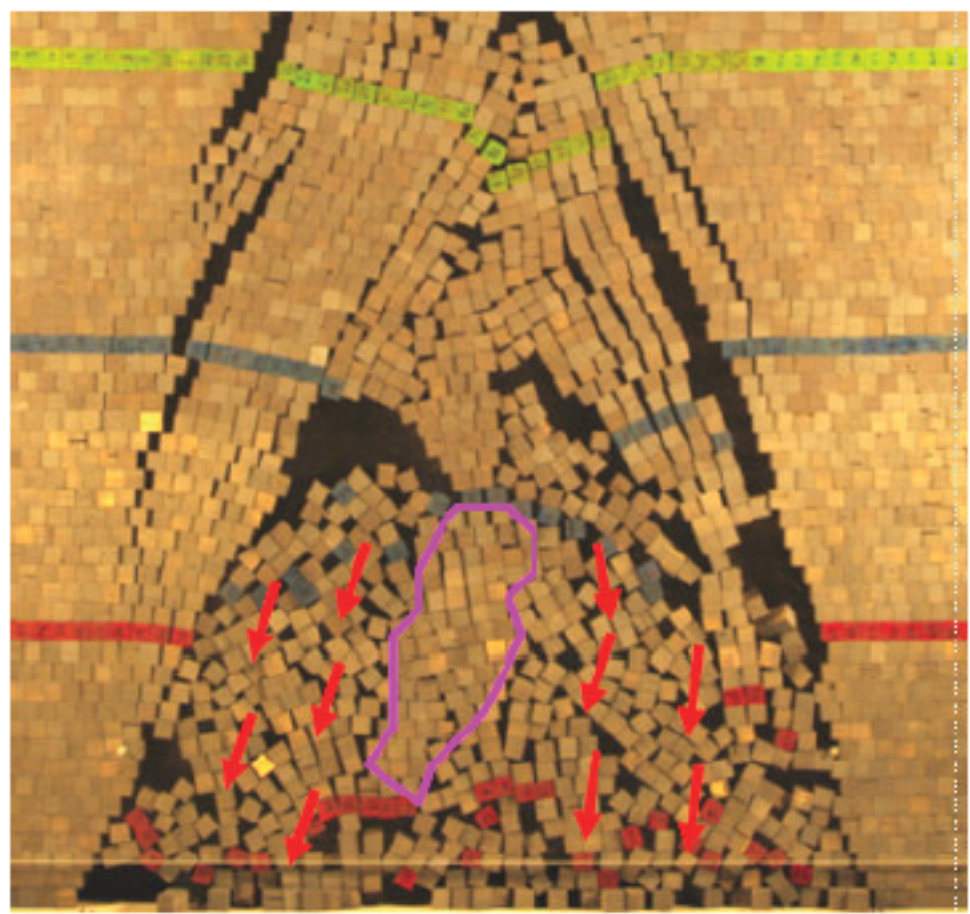

Figure 7 Large interlocking mass of particles (magenta) acts to disturb the flow of the fully dilated zone (red arrows) (after Sharrock \& Hashim 2009)

Scale models were used to establish the early fundamentals of granular flow, including ellipsoid theory which is still accepted as a general model for cave flow patterns. Many practitioners have understood that scaled physical models provide a means to understand granular flow phenomena but have limitations. These limitations relate to the ability to replicate actual underground mining conditions sufficiently for the use of developing mine design guidelines (Sandstrom 1972; Panczakiewicz 1977; Peters 1984; Power 2004; Garces et al. 2016). Physical models have been used extensively to simulate cave flow due to the difficulties undertaking full-scale measurements and trials in operating mines with an understanding of the limitations of the experiments. Similitude issues related to physical models compared to characteristics of operating mines are outlined in Table 1. 
Table 1 A comparison of physical model characteristics compared to operating mines

\begin{tabular}{|c|c|}
\hline Physical model & Operating mine \\
\hline Narrow particle size distribution & $\begin{array}{l}\text { Large size distributions from sand to large blocks } \\
\text { measuring }>10 \text { s of metres }\end{array}$ \\
\hline Rounded particle shape & $\begin{array}{l}\text { Highly variable particle shapes and sizes, mostly } \\
\text { angular blocks }\end{array}$ \\
\hline Single or small number of outlets & Up to hundreds of drawpoints \\
\hline Regular/even draw from outlets & Uneven draw patterns and volumes \\
\hline Smooth walls and model boundaries & Rough blasted rock surfaces \\
\hline Low overburden pressure & High overburden pressure \\
\hline No cave shape or cave propagation effects & $\begin{array}{l}\text { Cave flow impacted by cave shape, including rilling } \\
\text { effects }\end{array}$ \\
\hline Cannot account for blasting in SLC mines & $\begin{array}{l}\text { Blasting known to significantly impact cave flow and } \\
\text { material compaction }\end{array}$ \\
\hline
\end{tabular}

Halim (2006) discusses similitude issues related to the sand models conducted by Marano (1980) and Heslop \& Laubscher (1981) that were used to develop the drawpoint spacing guideline provided in Laubscher's 1994 state-of-the-art paper. Some of these issues include:

- The model dimensions were $760 \mathrm{~mm}$ long $\times 760 \mathrm{~mm}$ wide $\times 2,400 \mathrm{~mm}$ high. The scale of the model was 1:80 which translates to an ore block of $60 \mathrm{~m}$ long $\times 60 \mathrm{~m}$ wide and $192 \mathrm{~m}$ high.

- The outlets were $25 \mathrm{~mm}$ wide which scales up to a drawpoint width of $2 \mathrm{~m}$. Modern block caves generally use 4 to $5 \mathrm{~m}$ wide drawpoints. SLC mines commonly use $6 \mathrm{~m}$ wide crosscuts.

- The holes were spaced at $108 \mathrm{~mm}$ apart, or $8.64 \mathrm{~m}$ when scaled up. Holes were blocked in the experiments to simulate different drawpoint spacings. Drawbell spacing in modern caving mines is much larger, and generally in the order of 15 to $30 \mathrm{~m}$.

- The experiments used river sand or a mixture of river and pit sand. The median $\mathrm{P}_{50}$ particle size of the sand combinations used in the models varied between 0.6 and $0.7 \mathrm{~mm}$. This corresponds to a particle size of 48 to $56 \mathrm{~mm}$ when scaled up. Many block caves report $P_{50}$ fragmentation in the order of 300 to $500 \mathrm{~mm}$ (Brunton et al. 2016b). SLC mines report $P_{50}$ fragmentation in the order of 200 to 300 mm (Power 2004; Campbell 2019).

- The friction angle of the sand was $34^{\circ}$. This is much lower than the $45^{\circ}$ often measured in caving mines.

- Drawpoints in the model were drawn simultaneously, while drawpoints in operating mines are drawn unevenly and incrementally over short time periods.

It should be noted the caving mines in operation, during the period of testing by Marano (1980) and Heslop \& Laubscher (1981), were of similar dimensions to those of the scaled up mining dimensions according to benchmarking by Flores \& Karsulovic (2000). Fragmentation in the weak rock masses of early caving mines may have also been more comparable to the scaled up fragmentation from the sand models. As a result, the similitude issues of the block caves being mined at the time the drawpoint spacing guidelines were established may have not been significant. However, measured cave flow in modern cave mines has diverged from measurements in physical models, as the scale of modern caving mines has increased. 


\section{$2.2 \quad$ Full-scale trials}

Gravity flow measurements in operating mines, i.e. full-scale, provide essential information regarding flow behaviour and enables validation of mathematical models. However, only a small number of full-scale trials have been conducted to date because of the cost, time and difficulty associated with conducting these tests. Technology has also been a limitation historically, which prevented some cave flow behaviour from being measured in operating mines. A summary of published full-scale experiments and the methods used to measure cave flow is provided in Table 2.

Table 2 Summary of full-scale cave flow trials

\begin{tabular}{|c|c|c|c|}
\hline Mine & Type of cave & Year & Method of measurement \\
\hline $\begin{array}{l}\text { Grängesberg } \\
\text { (Sweden) }\end{array}$ & SLC & 1975 to 1982 & $\begin{array}{l}14,650 \text { markers made from } 300 \mathrm{~mm} \text { long pieces } \\
\text { of red plastic tube. Visual marker recovery }\end{array}$ \\
\hline $\begin{array}{l}\text { Chinese iron ore } \\
\text { mines (China) }\end{array}$ & SLC & 1969 to 1970 & $\begin{array}{l}3,520 \text { pipe or wood-filled plastic tube markers } \\
\text { held in place using small pieces of wood and clay } \\
\text { in three different SLC mines. Visual marker } \\
\text { recovery }\end{array}$ \\
\hline Kiruna (Sweden) & SLC & 1995 to 1997 & $\begin{array}{l}991 \text { markers made of } 1 \mathrm{~m} \text { lengths of cable } \\
\text { covered in red plastic }\end{array}$ \\
\hline $\begin{array}{l}\text { Ridgeway } \\
\text { (Australia) }\end{array}$ & SLC & 2002 to 2006 & $\begin{array}{l}\text { Over } 20,000 \text { markers made of } 250 \mathrm{~mm} \text { long steel } \\
\text { tube and filled with grout. Detection was mostly } \\
\text { via manual recovery from the steel picking belt }\end{array}$ \\
\hline $\begin{array}{l}\text { Perseverance } \\
\text { (Australia) }\end{array}$ & SLC & 2004 to 2005 & $\begin{array}{l}1,762 \text { concrete filled steel markers. Markers were } \\
\text { recovered visually and magnetically in the } \\
\text { materials handling system }\end{array}$ \\
\hline $\begin{array}{l}\text { Cadia Valley } \\
\text { (Australia) }\end{array}$ & $\begin{array}{l}\text { Block and } \\
\text { panel cave }\end{array}$ & 2008 to 2012 & $\begin{array}{l}\text { Approximately 3,000 and 2,500 SMART markers } \\
\text { were installed at Ridgeway Deeps and Cadia East } \\
\text { PC1, respectively }\end{array}$ \\
\hline El Teniente (Chile) & Block cave & 2012 to 2015 & 308 SMART markers \\
\hline Argyle (Australia) & Block cave & 2014 to 2015 & $\begin{array}{l}13 \text { Cave Tracker beacons. This was the first } \\
\text { published trial of the system in an operating mine }\end{array}$ \\
\hline $\begin{array}{l}\text { Ernest Henry } \\
\text { (Australia) }\end{array}$ & SLC & 2015 to 2018 & Approximately 10,000 electronic SMART markers \\
\hline
\end{tabular}

Early recovery measurements were conducted in SLC mines using markers installed between the blast rings. These trials measured the extraction zone (in the near-field) as markers were recovered. Mining dimensions at these mines were much smaller than contemporary SLC mines. Marker recovery at the Grängesberg SLC showed general agreement with measurements in scale models conducted by Janelid (1972). Measured draw zones at three Chinese iron ore SLC mines were interpreted as roughly elliptical in shape and corresponded to early physical model experiments (Gustafsson 1998).

Marker trial results from the Kiruna SLC showed high recovery from the centre of the blasted ring and very low recovery from the outer portion of the blasted ring (Gustafson 1998). Recovery patterns corresponded to ellipsoid theory. Quinterio et al. (2001) reported that increasing the burden from 3 to $3.5 \mathrm{~m}$ reduced recovery and increased dilution. Increasing the crosscut width from 7 to $11 \mathrm{~m}$ resulted in higher ore recovery.

The largest marker trial undertaken to date was completed at the Ridgeway SLC by Power (2004). Experimental results found that interactive draw does not occur in SLC mines as the draw width is narrower than the crosscut spacing in contemporary SLC mines (Power 2004). Dilution was found to be extracted at 
less than $20 \%$ draw, much sooner than the $50 \%$ dilution entry point taken from the dilution entry nomogram developed by Kvapil (1992), and republished by Bull \& Page (2000). Experimental results from the Ridgeway SLC were a step change in the understanding of gravity flow due to size of the programme and the density of markers. The experiments demonstrated that previous recovery forecasts in the literature were overly simplified and that interactive draw did not occur in contemporary SLCs as previously speculated.

The field trials at the Perseverance SLC were similar to those undertaken by Power (2004) and yielded somewhat similar results. The experiments found no evidence of interactive draw and the maximum width of draw was $11.5 \mathrm{~m}(+/-1 \mathrm{~m})$ (Hollins \& Tucker 2004). Hang-ups were found to enable material at the back of the ring to be recovered and corresponded to wider marker recovery (McDonald 2004). This observation is similar to the physical model measurements described by Laubscher (1994) and Stazhevskii (1996) where hang-ups result in wider extraction zone geometry.

A series of experiments were conducted at the Ernest Henry SLC to test the effects of ring burden, explosive density and crosscut height on recovery and cave flow behaviour (Campbell 2018a, 2018b). The experiments also measured the effect of design variables on detonation performance and fragmentation. The objective of the experimental programme was to test design variables hypothesised in the literature to increase ore recovery. The trials identified that none of the tested hypotheses improved recovery and, in most cases, the opposite occurred. For example, reducing ring burden was speculated to increase ore recovery if matched to the depth of the drawzone. However, reducing ring burden caused over-compaction of the blasted ore and resulted in lower recovery and early dilution entry. Conversely, increasing the ring burden prevented over-compaction and resulted in the highest recovery of all the trials conducted. Until these experiments, the effects of blast compaction were not previously identified or quantified. The full-scale trials also measured the effects of blasting, which cannot be adequately replicated in physical models. The experiments by Campbell (2019) demonstrated that significant unknowns and unquantified phenomena impacting cave flow still exist and additional measurements in operating mines are required.

Brunton et al. (2016a) describes marker recovery results from both the Ridgeway Deeps block cave and Cadia East PC1 panel cave which contradict conventional (or idealised) flow theory. The experiments identified complex extraction zone evolution and drawzone geometries that do not match the evolving ellipsoids in idealised flow theory. Brunton et al. (2016a) noted marker recovery above the major apex occurred at all heights and there was no clear height of interaction. It was proposed the marker recovery patterns were caused by complex flow behaviour including arching, interlocking of large particles, and fines percolation. They also explain that these processes are dynamic and the arches, interlocking, and preferential flow paths break and reform throughout the cave muckpile over time. The marker recovery and postulated flow behaviour observed by Brunton et al. (2016a) was also described as being similar to the disturbed flow theory described by Sharrock \& Hashim (2009). Additional measurement in operating mines, including measurement of the mobilised zone, was recommended by Brunton et al. (2016a).

SMART markers (Whiteman 2010) were installed at Esmerelda Block-2 at El Teniente to determine if interactive draw was occurring between drawbells, and to measure the impact that different load-haul-dump (LHD) loading patterns had on recovery. The main finding from the experiments was the drawpoint spacing of $30 \times 20 \mathrm{~m}$ resulted in interactive draw conditions for adjacent draw zones (Garces et al. 2016). Although the drawpoint spacing is outside of the interactive draw guidelines proposed by Laubscher (1994), it was suggested that it is possible to increase the drawpoint spacing and still achieve interactive draw (Garces et al. 2016). The benefits of increasing the spacing are the decreased development costs and improved extraction level stability. Garces et al. (2016) also compared drawzone recoveries for two drawbells with different extraction methodologies. The experiments found that different drawpoint loading, i.e. even versus uneven loading, results in different flow behaviour. Drawing from a single drawpoint caused more irregular material flow compared to material recovery when both drawpoints were loaded concurrently. The trials at El Teniente highlight the complexity of disturbed flow in large block cave mines and the potential implications for drawpoint spacing as caving mines move outside the realms of existing design guidelines. 
Full-scale experiments to date have measured the extraction zone by recovering different forms of cave markers installed prior to cave propagation or ring blasting. Measurement of the movement zone was not possible until the recent development of the Cave Tracker system (Whiteman et al. 2016). The first published trial of the Cave Tracker system was undertaken at the Argyle block cave. A total of 13 beacons were installed and the movement in the cave was tracked in 3D and in real-time (Whiteman et al. 2016). The beacons measured cave flow behaviour including even drawdown (i.e. mass flow), periods of rapid movement for some beacons (demonstrating variable flow velocity in both time and space) and lateral movement. The development of the Cave Tracker system is regarded as a significant technological development that now enables previously unquantified cave flow behaviour to be measured.

Existing unknowns regarding cave flow and additional trials in operating mines are required to measure existing unknowns. This includes characterising the movement zone, measuring disturbed flow behaviour, and collecting data that will enable validation and calibration of numerical cave flow models.

\subsection{Cave flow simulation}

Various numerical approaches have been used to describe gravity flow and forecast recovery in caving mines. The advantages of numerical methods for simulating gravity flow are the speed, simplicity and repeatability compared to full-scale measurements. Cave flow simulation has multiple applications, including:

- Tonnes and grade estimation for economic evaluation of potential caving mines in the study phase.

- Trade-off studies for mining method selection.

- Comparison of different mine designs, extraction level layout and footprint elevation.

- Cutoff grades assessment and draw strategy optimisation.

- Grade forecasting in operating mines, including production reconciliation.

- Ore reserve estimation.

Various types of flow simulation software exist. Some programs have been calibrated using scaled measurements from 2D and 3D physical models due to an absence of measurement in operating mines. Other mine-scale flow models have been calibrated using data from field experiments which has improved ore recovery reconciliation. Advances in software and computing power have also enabled cave flow simulation to be linked to modelled cave propagation. This is known as coupled granular flow-deformation modelling (Beck et al. 2011). The advances in granular flow simulation and cave modelling are described here. Current limitations and knowledge gaps related to cave flow simulation and recovery forecasting are also discussed.

Template mixing tools such as PCBC (Dassault Systèmes 2020) use empirical caving rules and assumptions which can be modified by the user to simulate material flow within the cave column (Burgio \& Diering 2008). Stochastic methods such as void diffusion and cellular automata (CA) simulate movement of discretised blocks used to represent granular media using probabilistic functions (Power 2012; Sharrock \& Hashim 2009). These codes include PGCA (Power 2012), CAVESIM (Herbert \& Sharrock 2018), and FLOWSIM (Castro et al. 2016). An example of a CA flow model of a sublevel cave is provided in Figure 8. Models are often calibrated using results of physical models or grade reconciliation data (Castro et al. 2016; Campbell \& Power 2016). Model validation using marker recovery measurements has been undertaken by Power \& Campbell (2016), and Campbell \& Power (2017). Model parameters for physical behaviour such as width of draw or fines migration can be altered as a user input. These types of models have no particle-to-particle physics, as part of the flow simulation and the evolution of the extraction zone is a function of the user inputs and stochastic particle movement. 


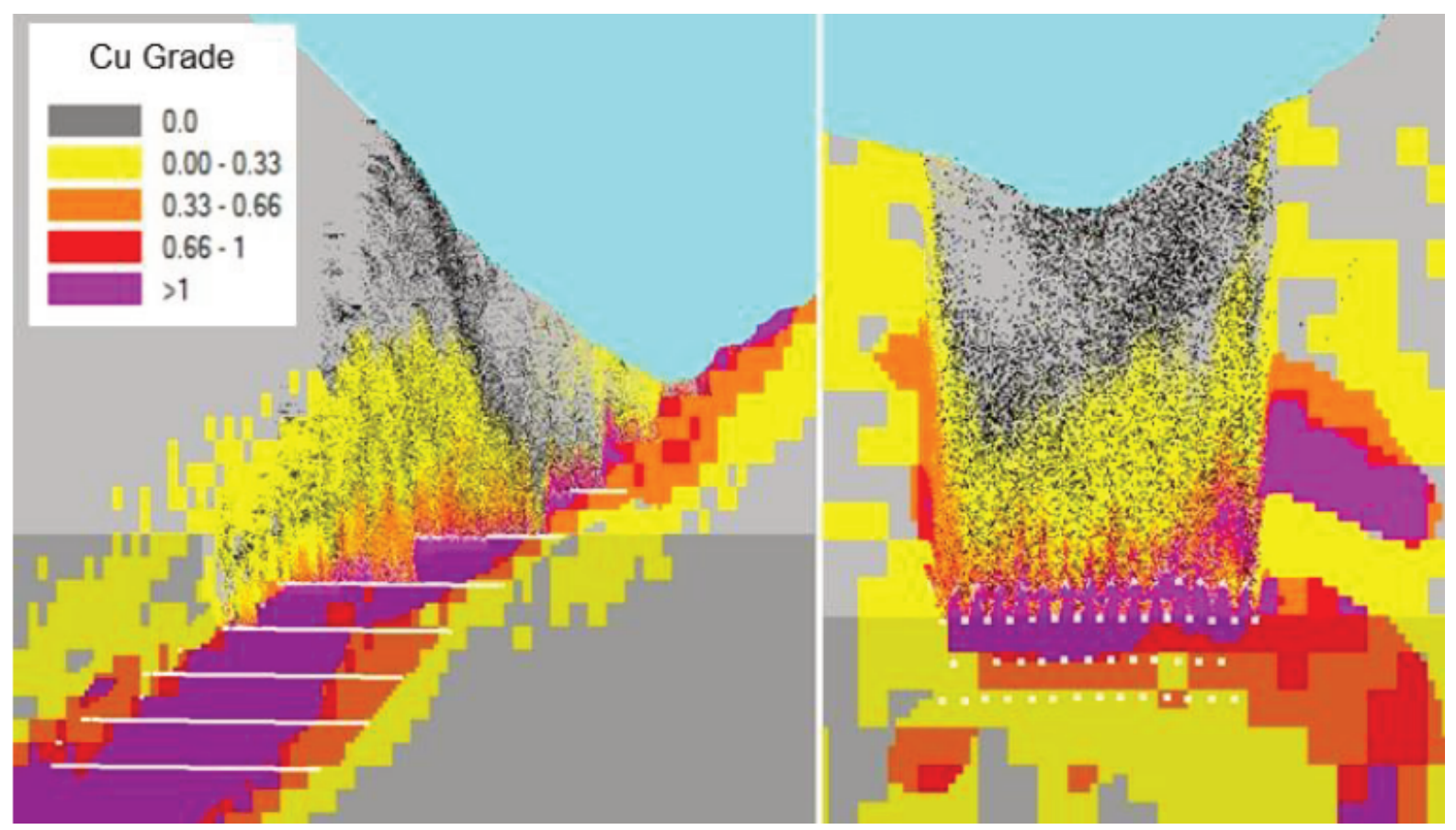

Figure 8 Cross-section through a CA flow model showing grade mixing and drawdown during a model simulation (Campbell \& Power 2016)

One of the limitations of template mixing and CA based codes is that the cave is assumed to propagate when the cave is drawn. This of course may not be the case for many caving mines. Some CA codes enable the user to prescribe delayed caving or input a cave shape/geometry to limit cave growth. This ensures cave flow does not extend beyond the forecasted cave boundary.

Cave propagation and the geometry of the caved zone impacts the shape of the muckpile, rilling inside the cave and the amount of broken material available for draw. The muckpile height and drawdown of the caved material changes the stress conditions of the intact rock leading to additional cave propagation. Cave propagation and cave flow are therefore inherently linked by physical processes. This led to the development of coupled, granular flow-deformation simulations to forecast cave initiation, propagation and gravity flow in the same modelling framework (Beck et al. 2011). The tool combines a CA representation of the cave muckpile with an explicit discontinuum finite element (DFE) model of the rock mass. A handshake process between the two software codes after each mining step enables both cave propagation and muckpile drawdown to evolve realistically. An example of a coupled DFE-NCA model overlaid with cave monitoring data is provided in Figure 9. 


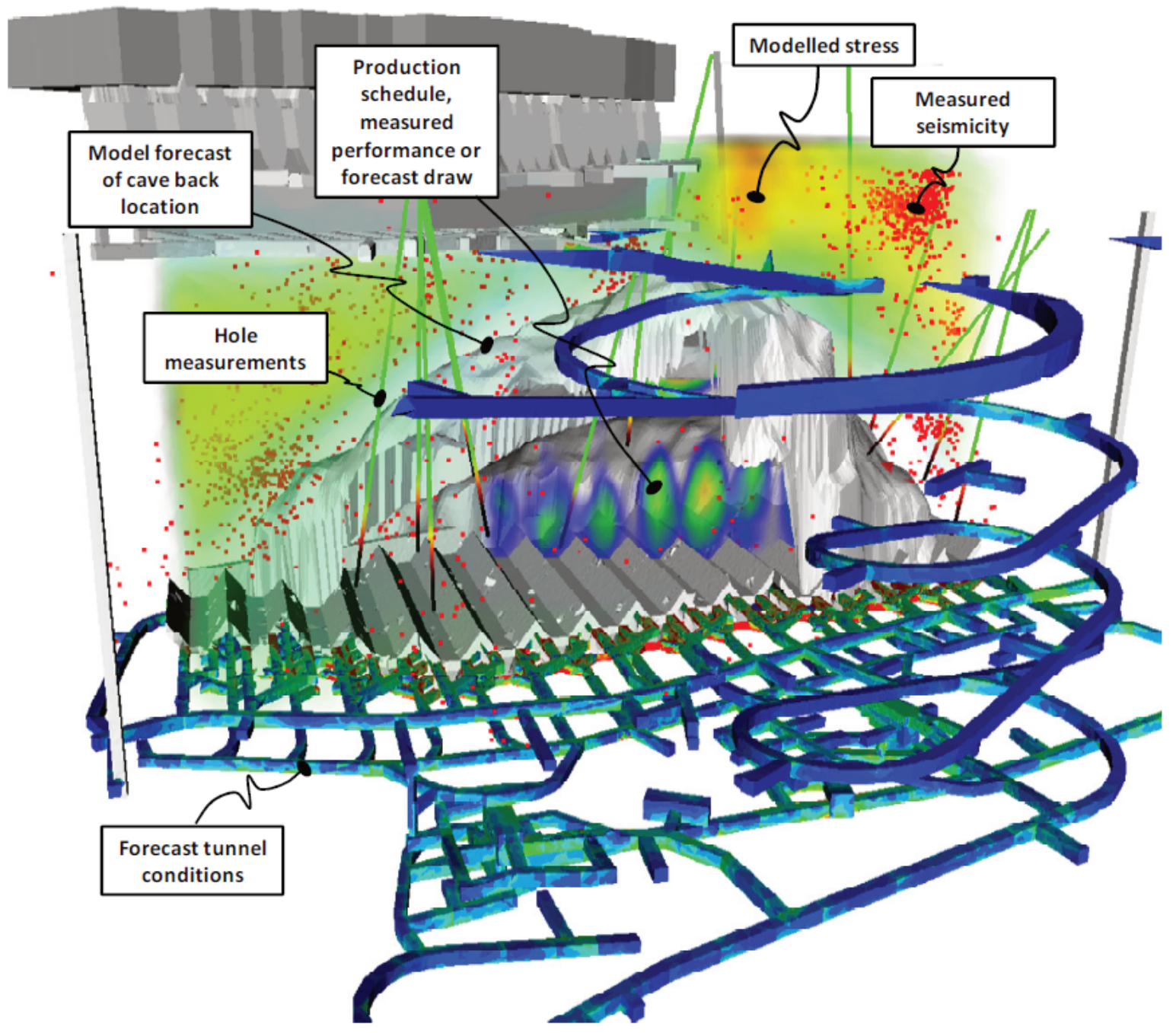

Figure 9 Example of a coupled DFE-NCA model results including monitoring data from multiple sources visualised in 3D (after Beck et al. 2011)

The discrete element method (DEM) is possibly the most established and versatile tool for modelling physical behaviour of granular materials. This is because DEM algorithms incorporate the physics of particle contact forces and interaction (DeGagne \& McKinnon 2005; Hancock 2013; Minchinton \& Dare-Bryan 2005; Sellden \& Pierce 2004). Particle behaviour such as displacement, velocity and rotation are captured by the model, as well as the normal and shear forces acting on individual particles. The main limitation of DEM models is the computational requirements, which prevents mine-scale simulation that requires hundreds of millions of individual particles. Early DEM simulations of cave flow were generally limited to a few drawpoints and draw columns in the order of $30 \mathrm{~m}$ high (Pierce \& Hakan 2004). Limitations in computing, long model run times, and prevented mine-scale simulation of cave flow lead to development of an emulator software code, or Rapid Emulator Based on PFC (REBOP) (Lorig \& Cundall 2000; Pierce 2010). REBOP uses flow algorithms derived from PFC flow simulations to approximate the physics-based flow simulation. This improved the model's processing speed and reduced computational requirements to enable life-of-mine simulations to be conducted within a practical time frame. A consequence of using empirical flow algorithms is that the particle-to-particle physics is no longer explicitly captured in the simulation.

The limitation of stochastic based codes when replicating complex physics associated with particle flow and the restrictive computational requirements of traditional DEM methods, has created the need for alternative approaches to simulate cave flow. This has led to the development of numerical frameworks that allow: (i) fast and efficient modelling of granular flow mechanisms in very large domains of material; and (ii) the 
exchange of physically relevant information when the code is used in a coupled cave flow-deformation modelling framework. The latter means that the algorithm should be able to exchange not only particle positions and velocities for each particle, but also forces and stresses in the muckpile within a coupled modelling scheme.

Significant software advances have led to the development of fast algorithms for particle flow simulations. These include the application of computer graphics algorithms to visualise behaviour of particles and granular materials. The requirement to simulate particle behaviour in real-time in non-mining applications has been the main driver for the early development of such codes. One way to overcome the computational limitations of DEM, but maintain a similar physics-based approach, is the use of algorithms that show a more robust and efficient solution for the underlying equations. This includes mathematical approaches that can be solved on massive parallel computing platforms such as compute unified device architecture (CUDA) technology, which allows a large parallelisation of the algorithms.

One promising approach is the position based dynamics method (PBD) (Müller 2006; Bender et al. 2014; Kloss et al. 2012; Macklin et al. 2014) and recent improvements of the algorithm as the extended position-based dynamics (XPBD) algorithm proposed in Macklin et al. (2016). The use of such numerical methods maintains the basic idea and advantages of the DEM methodology. However, PBD based methods provide significant advances in terms of computational efficiency and provide the power to solve large particle flow based problems, such as those experienced in cave mining. The ability to simulate problems with many millions of discrete particles where the particle interaction and dynamics can evolve freely under gravity and unstable flow processes allows the integration of such an algorithm into a coupled flow-deformation modelling framework. The nature of flow and the resulting muckpile inside the cave evolves from the constitutive properties of particles. The PBD method for simulating cave flow and muckpile shape can now be used to replace the NCA component for coupled simulations. Examples of PBD used to simulate particle movement in a coupled framework are shown in Figures 10 and 11.

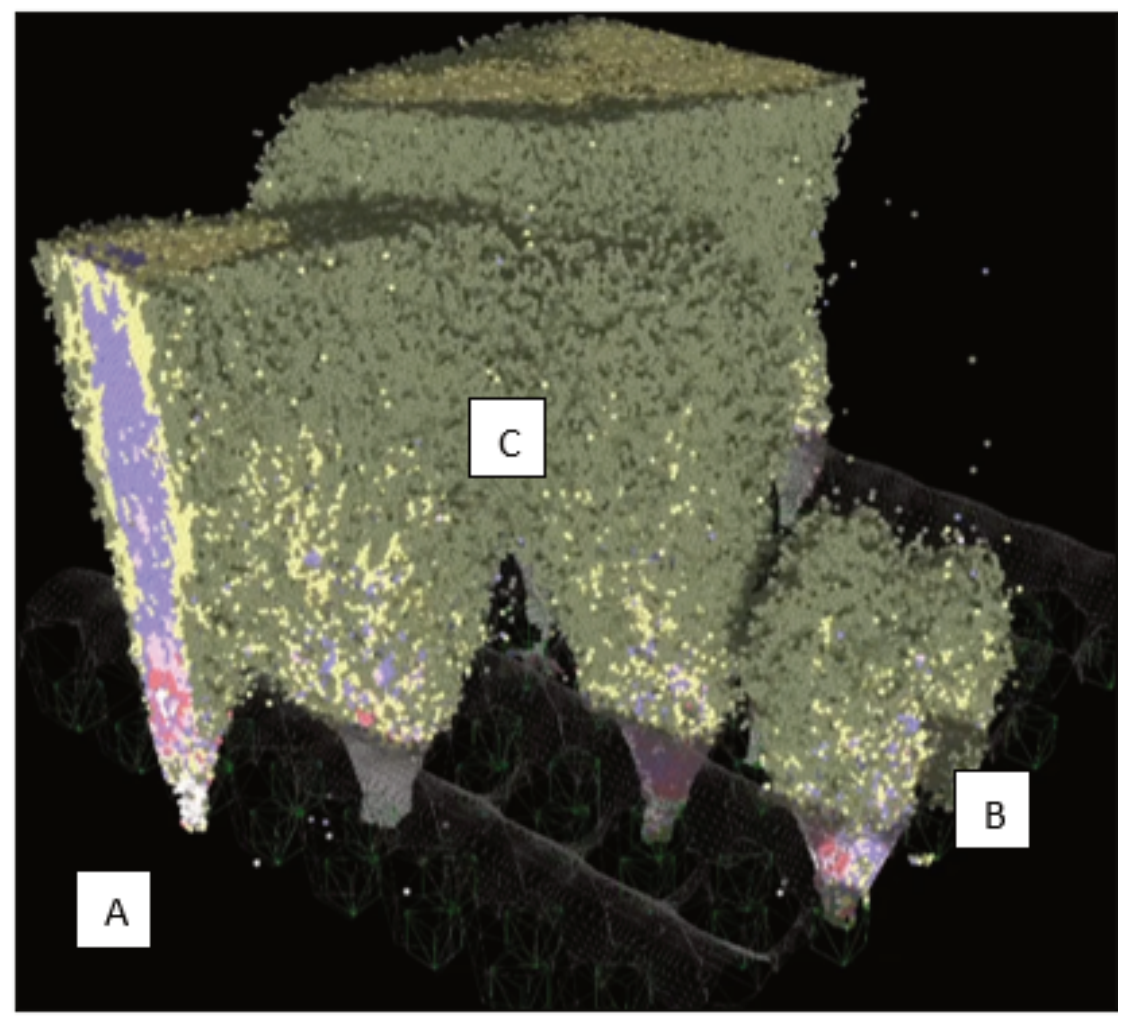

Figure 10 Near-field flow mechanics captured in a position based dynamics simulation. (a) Extraction zone above a drawpoint; (b) Isloated movement zone; (c) Interacting movement zones. Particles are coloured by velocity with low velocity particles hidden 

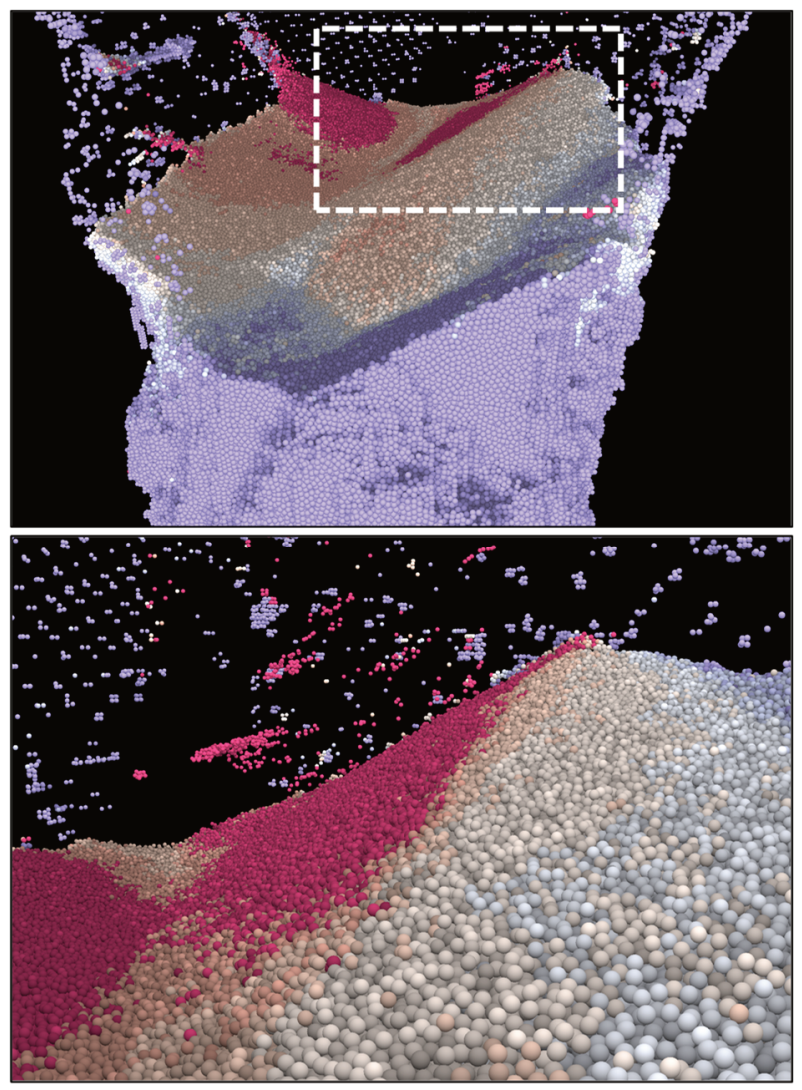

Figure 11 Example of far-field flow behaviour including rilling in a subsidence zone in a positions based dynamics (PBD) model. Particles are coloured by velocity

The next step of the cave modelling journey is tighter coupling, i.e. smaller mining steps, of the rock mechanics algorithm with the gravitational flow simulation, using the potential of modern DEM methods such as PBD. This would enable the use of stresses and forces as handshake information for the smaller coupling steps for full-scale simulation of caving mines.

Computing power and ability to simulate large engineering problems and complex physics have advanced much faster than case studies of cave flow measurement. Although a full representation of every physical particle interaction is not possible in current simulation tools, rapid advances are being made. What is clear is that the advances in flow simulation outpaced the measurement and quantification of flow behaviour in caving mines; particularly the new paradigm of caves that are larger, deeper and operating in stronger rock. This has led to a gap between modelling capability and data available for validation of models that are used to evaluate and design caving mines. The next section of the paper explores cave mine design with respect to cave flow and recovery.

\section{$3 \quad$ Mine design factors impacting cave flow and ore recovery}

Drawpoint spacing is one of the most important and controversial design parameters in cave mining (Laubscher 2000). On one hand, engineers may be focused on grade and recovery and therefore target close drawpoint spacings. This results in smaller pillars which have potential stability implications and required more development, which impacts cave establishment time and costs. Conversely, some engineers may opt for larger drawpoint spacing for improved stability, or to enable the use of larger LHDs or to reduce development requirements. One of the major considerations of the mine design process in caving mines is the implication that drawpoint spacing has on recovery and stability. In theory, the optimum drawpoint spacing for maximising recovery and minimising dilution entry is to have the drawpoints spaced so the draw zones just overlap (Brown 2003). The drawzone geometry being a function of the fragmentation size in idealised flow theory and drawpoint spacing guidelines by Laubscher $(1994,2000)$. The relationship between 
drawzone interaction and mine design in ideal flow conditions is illustrated in Figures 12 and 13. However, as previously discussed, existing design guidelines are based on scaled sand models with multiple similitude issues and idealised flow theory which has been challenged in recent cave flow studies at El Teniente and Cadia Valley.

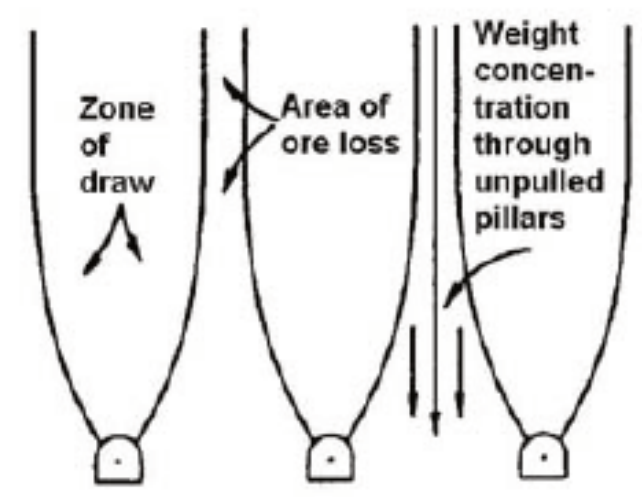

(a)

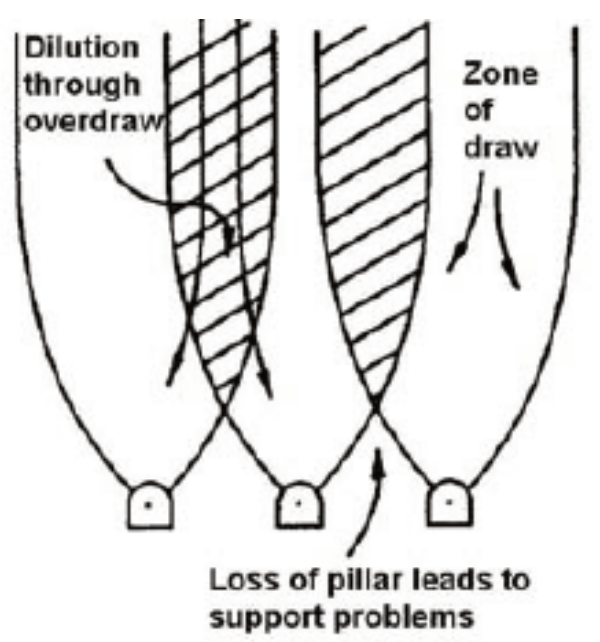

(b)

Figure 12 A vertical section through conceptual drawpoints showing excess spacing with (a) Non-overlapping extraction zones; and (b) Close spacing with overlapping draw zones (after Brown 2003, original after Richardson 1981)

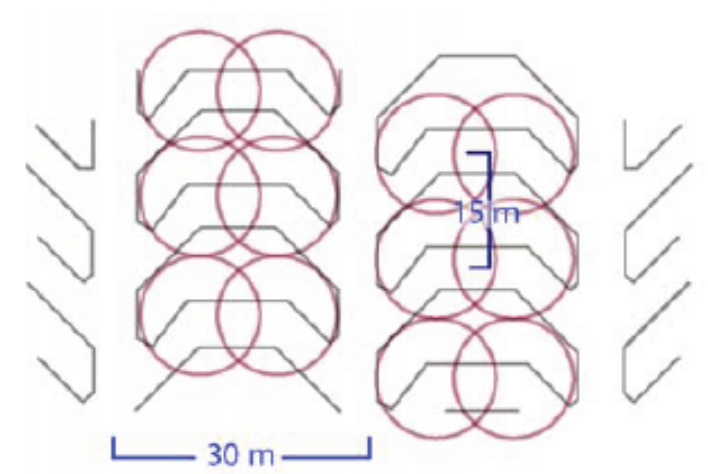

(a)

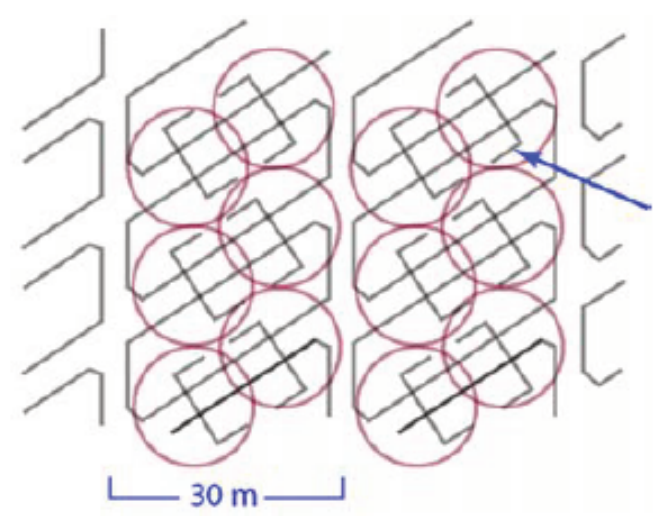

(b)

Figure 13 Plan view of an (a) Offset herringbone and (b) El Teniente layout showing $16 \mathrm{~m}$ wide draw zones for $15 \times 30 \mathrm{~m}$ drawbell spacing (after Brown 2003)

Caving mines continue to be mined deeper, with higher lift heights, increasing footprint dimensions and greater production rates. This has given rise to what has been termed 'super caves' (DeWolffe \& Ross 2016). Benchmarking by Flores \& Karzulovic (2000) shows the evolution of extraction level design and drawbell spacing. The benchmark found that before 1970, the average production drift spacing was $14 \mathrm{~m}$ and average drawpoint spacing was $8 \mathrm{~m}$. These dimensions increased to an average of 21 and $12 \mathrm{~m}$ for the period between 1970 and 1990. From 1990 to 2000, the dimension increased to 26 and $16 \mathrm{~m}$. Since 2000, drawpoint spacing has continued to increase, including Esmerelda and DMLZ $(30 \times 20 \mathrm{~m})$ and Cadia East PC1 $(32 \times 20 \mathrm{~m})$. Mining depths have also continued to increase over time and now extend below depths of $1 \mathrm{~km}$. These mines include Ridgeway Deeps $(1,100 \mathrm{~m})$, Cadia East $(1,200 \mathrm{~m})$ and Oyu Tolgoi $(1,300 \mathrm{~m})$. The Resolution mine is currently assessing caving options at a depth of $2,000 \mathrm{~m}$ below surface (Gantumur et al. 2016). As mines become deeper, increased stress conditions and overburden pressure inevitably requires larger pillars, and therefore wider drawpoint spacing. 
The potential implication of larger drawbell spacing includes lower recovery and early dilution entry (Van As \& Van Hout 2008). Conventional flow theory would suggest that the wide spacing of drawpoints leads to lower recovery and early dilution entry. While recent measurements in operating block caves demonstrating wide draw caused by disturbed flow, the question still remains, how wide is too wide for drawpoint spacing? As outlined in Section 3, the complexities and interdependencies of variables impacting cave flow are generally understood, but yet to be measured sufficiently for the purposes of mine design or validation and calibration of numerical flow models used to simulate recovery and stability in caving mines.

Drawpoint spacing and mine layout must consider stability, particularly as mines become deeper and operate in more adverse stress conditions. Widespread instability in a block cave or sublevel cave can lead to significant loss of recovery. Reducing the size of extraction level pillars to improve (theoretical) recovery can actually reduce recovery if widespread deformation occurs due to undersized pillars (Beck et al. 2016). Instability due to undersized pillars may lead to recovery losses far greater than those that would have been achieved by placing the drawpoints closer together. This means the stability and recovery problem is not a direct trade-off, as instability also causes recovery loss if heavily damaged parts of the footprint cannot be accessed for ore loading.

The overall mining strategy, including undercutting sequence, cave front angle and front length, can impact footprint stability just as much, if not more than the pillar sizing alone (Beck et al. 2016). Beck et al. (2016) also noted that the purpose of increasing pillar sizes should not be to ensure stability of every pillar, but to ensure that pillars are sufficiently large to arrest deformation in areas of weak ground and prevent instability from migrating and impacting a larger area of the footprint, and inevitability resulting in additional loss of recovery. Stegman et al. (2018) recounted the learnings of five caving operations and noted "there is little value seeking to maximise reserve recovery by reducing pillars to the point where they cannot withstand caving-induced stress and the load of the muck pile, resulting in the premature loss of drawpoints". It is also important to acknowledge that recovery is not only influenced by drawpoint spacing and mine stability. Recovery is significantly impacted by factors such as cave underbreak and early closure of drawpoints due to fines and/or water.

The reliance on design guidelines based on small-scale models with multiple similitude issues is not isolated to block cave mines. SLC mines also rely on generalised guidelines and rules of thumb that have limited measurement or verification from full-scale measurements. Since all the ore in SLC mines is blasted, these mines rely on consistent blasting results for productivity and optimised blast design to maximise recovery and economic return. SLC blast design guidelines in the literature are summarised by Brunton (2009), who notes multiple limitations. Existing design guidelines do not account for the rock strength or stiffness, degree of jointing of the rock and do not aim to maximise ore recovery. Modern SLC mines still use rules of thumb, such as the blast ring burden should be 25 times the hole diameter. This is why SLC mines such as Ernest Henry, Ridgeway and Telfer all use $2.6 \mathrm{~m}$ ring burden, despite different rock mass and mining conditions. The guideline does not account for explosive density, number of blastholes, rock strength, rock jointing, and many other conditions that impact blast performance, fragmentation and recovery. The means that blast design and the corresponding mine layout in most SLC mines are unlikely to be optimal for the unique operating conditions of the mine.

Despite the importance of mine design on cave performance, the industry still relies on guidelines and flow simulations calibrated using sand models and idealised flow theory. Idealised flow theory has been demonstrated not to occur due to the increasing scale of caving operations, as shown by full-scale measurements outlined previously. This leaves the industry in a predicament - how to design new mines, sometimes requiring billions of dollars of capital, knowing that current design guidelines and idealised flow theory may not be valid? Without additional full-scale measurements to quantify cave flow for modern caving mines, the industry is at risk of continuing to design mines on the basis of conventional flow theory and cave flow models with limited field measurements to validate the input assumptions. Clearly more measurement is required. Fortunately, the critical technology to undertake these field measurements has been recently developed and is commercially available. 


\section{The role of technology and future experiments}

This paper has so far shown that despite significant research in the past 60 years, some cave flow phenomena has not yet been measured extensively, or in sufficient detail to update contemporary design guidelines or validate newly developed flow simulation techniques. One of the main reasons for this limitation is because cave flow measurement devices have only recently been invented. There has been extensive technology development in the past 10 years, including electronic cave markers, cave beacons, laser scanning for fragmentation measurement and wireless tiltmeters and piezometers. These technological developments now enable previously unquantified phenomena in caving mines to be measured in detail. This section of the paper outlines existing technology and applications to quantify cave flow. Examples of field experiments required to measure and quantify current unknowns, such as disturbed flow behaviour, are also provided.

\subsection{Cave markers}

Multiple devices have been used in caving mines to measure recovery. These include tyres, pieces of wood, lengths of cable, steel markers and more recently, specifically designed electronic markers known as SMART markers. SMART markers are a blast-resistant radio-frequency identification devices (RFID) specifically designed to measure ore recovery in caving mines. The devices are generally installed in specifically drilled holes and grouted in place. The markers then flow as part of the caved material and are then recorded using antennas once they are loaded from drawpoints. SMART markers provide significant advantages compared to steel markers, as outlined by Steffan \& Kuiper (2012).

Subsequent generations of SMART markers now enable in-ground communication between markers. These are known as network SMART markers. Additional functionality such as tilt detection and porewater pressure measurement has also been developed. These devices have multiple applications including monitoring cave propagation, changes in porewater pressure and drawdown due to caving, as well as pit interaction and pit slope instability. These devices have benefits over wired instruments such as time-domain reflectometers (TDR) and piezometers in some applications. The markers have some limitations including battery life, which is in the order of 10 years, and wireless signals can be impacted by high levels of magnetite and iron-rich rock.

Another type of RFID tracking device is the SmartTag (METSO). These devices were developed for tracking of ore from mine-to-mill or pit-to-port scenarios, and have generally targeted open pit operations. The devices are made in a range of sizes and are generally much smaller than SMART markers. Some mines are considering the use of SmartTags, in addition to SMART markers and other devices, as a means to track the flow rate of small particles and measure fines flow (Hocking et al. 2018).

\subsection{Cave trackers}

The Cave Tracker system (Whiteman et al. 2016) is designed to track movement of cave rock in real-time using high sensitivity magnometers (detectors) to measure the positions of spinning magnets (beacons) which are installed into the rock prior to cave propagation (Whiteman et al. 2016). Detectors generally have a reliable range of $180-200 \mathrm{~m}$ and beacons require three detectors in range for 3D positioning. Cave monitoring using this system now enables the movement zone to be tracked in 3D and in real-time. An array of markers and beacons could be used to provide valuable measurements to assess various cave flow behaviour, including:

- The evolution of the extraction zone and the movement zone throughout the cave muckpile.

- Relative movement of cave material above drawpoints and apexes at various heights of the muckpile.

- Interactive and isolated draw zones, including the height of interaction.

- Patterns in muckpile movement, including disturbed flow.

- Lateral movement and rilling in the cave.

- Relative flow velocity of fines (if markers of various sizes are installed). 


\subsection{Fragmentation measurement}

Various fragmentation assessment methods exist at present, including physical screening, 2D and 3D image analysis, and laser scanning techniques. Campbell \& Thurley (2017) provide a synopsis of available techniques for fragmentation measurement, including advantages and disadvantages of each system in an underground mining environment. Routine fragmentation of drawpoint muckpiles without disrupting operations and automated processing is now possible (Campbell \& Thurley 2017). Low cost laser scanners could be also installed at drawpoints for regular fragmentation measurement without personnel accessing the footprint. The scanning and data processing is largely automated and could be adapted to enable high frequency fragmentation measurement. The importance of this data is for correlation with flow patterns and recovery measurements from SMART marker and Cave Tracker systems. An understanding of fragmentation during draw, including variability in particle sizes, will inevitably be required to explain measured flow behaviour, particularly disturbed flow. Measurements of fines in drawpoints could also be used as part of a broader mudrush hazard risk management system.

\subsection{Boulder detection}

Large rocks or boulders are known to cause hang-ups. Measurements in scale models and underground observations also demonstrate that large boulders cause flow blockages and disrupt normal flow patterns. Tracking cave flow with markers and measuring fragmentation is important; however, the causes of flow disruptions also need to be measured and correlated to the marker and beacon data. Although a commercially available boulder detection system is not yet available, there has been significant steps forward using ground penetrating radar (GPR) to identify oversize in proximity to drawpoints. Benter (2014) found that large rocks buried in a rock pile can be reliably detected and differentiated from smaller rock fragments, air pockets and irregular surfaces using GPR to measure signal velocity and attenuation through the cave muckpile. Although detection lengths are limited to being within relatively close proximity of a drawpoint, further development of the technology presents significant opportunity to understand cave flow. Detection of boulders could also act as an early warning system for a hang-up and potential disruptions to production.

\subsection{Footprint loading and deformation}

Stability is an important part of the design equation in terms of footprint layout, cave flow, and recovery. Pillars in both block caves and sublevel caves are subject to a complex evolution of stress paths during cave propagation and maturation. Stress cells installed in pillars throughout the cave footprint would enable the load history to be measured during cave flow trials and draw experiments. Stress cells combined with open holes to assess rock mass damage and extensometers to measure movement would enable pillar behaviour and stability to be assessed and numerical model forecasts to be validated.

Deformation measurement using laser scanning, or Lidar, offers high resolution and rapid measurement of movement and closure in underground drives (Jones \& Beck 2017). The purpose of deformation monitoring is to assess the rock mass response at the tunnel boundary with respect to measured stress change and pillar loading. Monitoring cave flow, as well as footprint loading and deformation, would enable a mine to characterise both recovery and stability for the specific footprint design and rock mass conditions of that mine.

\subsection{Future experiments and trials}

This paper has detailed the evolution of the current state of knowledge for cave flow behaviour, current mine design approaches, and the limitations of existing design guidelines. A series of trials and measurements have been proposed to measure disturbed flow behaviour and the evolution of the mobilised zone in operating mines. Each trial would provide valuable data for validation and calibration of numerical models. Data from multiple mines would enable correlations to be established. A combination of modelling and multiple field measurements could then be used to update existing design guidelines. 
A conceptual design of a trial is shown in Figure 14. The trial uses a combination of Network SMART markers combined with the Cave Tracker system in a block cave to measure the movement zone and the extraction zone to assess the evolution of material movement, including isolated draw, interactive draw and the height of interaction.

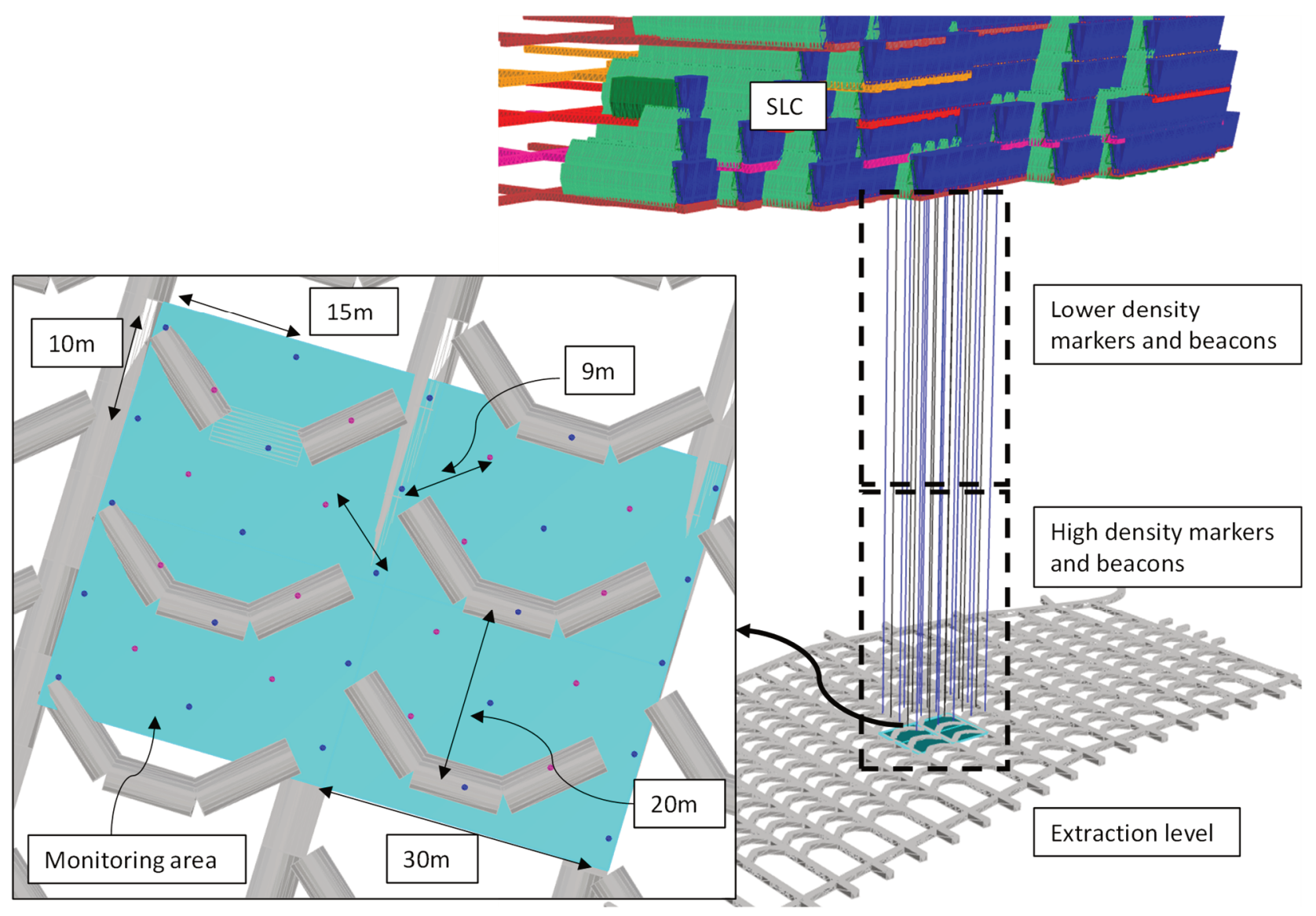

Figure 14 Example marker and cave beacon layout for a block cave

The marker layout includes:

- Holes spaced in rows at $15 \times 10 \mathrm{~m}$ apart in a $60 \times 40 \mathrm{~m}$ footprint. This spacing is to match the $30 \times 20 \mathrm{~m}$ drawbells spacing. Additional infill holes between the $15 \times 10 \mathrm{~m}$ grid reduces the maximum hole spacing to $\sim 9 \mathrm{~m}$, and provides additional marker coverage. This results in a total of 41 drill holes for the four drawbells.

- The drillhole layout provides coverage for four drawbells over the entire $300 \mathrm{~m}$ lift height. Larger drill hole spacing would not enable sufficient resolution to assess flow paths above drawpoints and apexes, nor provide sufficient data resolution to characterise isolated, interactive or disturbed flow conditions.

- A higher density of SMART markers and cave beacons is planned for the lower $150 \mathrm{~m}$ of the lift. This has been done to reduce instrumentation costs and to enable higher data resolution in the zone of isolated and interactive draw, where disturbed flow patterns are most likely to be measured. 
- In-hole Cave Tracker beacon spacing in the concept design is 10 and $30 \mathrm{~m}$ in the upper and lower sections of the drill holes, respectively. This is approximately 620 beacons in total. This may seem overtly high, however this spacing corresponds to one beacon for every $800 \mathrm{~m}^{3}$ in the lower section with $10 \mathrm{~m}$ spacing and 2,400 $\mathrm{m}^{3}$ for the upper section where beacons are $30 \mathrm{~m}$ apart in the hole.

- Network SAMRT markers are planned in the four corner holes only for tacking cave propagation. This is due to the close spacing required for the Network SMART markers to communicate with each other. A nominal $3 \mathrm{~m}$ spacing would be used to ensure redundancy for marker communication.

- SMART markers installed at an in-hole spacing of 10 and $20 \mathrm{~m}$ in the lower and upper sections respectively, except for holes installed with Network SMART markers, to measure recovery and the extraction zone.

- Additional SMART markers installed in upholes from the undercut level should also be considered. These markers, while more difficult to install and likely to interact with operations during cave establishment, would provide more detailed near-field flow and recovery information.

- The budget for this programme is in the order of AUD 3 million, including drilling and installation. Budgeting is based on indicative pricing at the time of writing. The 16 infill holes could be removed to reduce costs; however, the data resolution would be significantly impacted and would likely prevent disturbed flow conditions from being characterised.

The experimental layout has similarities to those conducted by Brunton et al. (2016a). However, these trials include Network SMART markers to assess cave propagation, SmartTags for fines percolation and the Cave Tracker system to measure the evolution of the mobilised zone and track flow paths in 3D. Routine fragmentation scanning would be undertaken at drawpoints. Deformation and pillar loading would be assessed using Lidar and stress cells in pillars, as previously described.

The purpose of the experiment is to measure disturbed flow in operating mines in various design and operational scenarios. The measurements should be repeated in different mining conditions to assess:

- Different draw conditions (i.e. continuous loading versus isolated loading).

- Effect of different drawpoint spacing.

- Effect of footprint design (i.e. offset herringbone versus El Teniente).

- Effect of undercut sequence and design.

- Ranges of fragmentation in different rock types and different mines.

Combining cave flow measurement with monitoring of fragmentation and boulder detection would enable cave flow behaviour to be correlated to fragmentation and flow disruptions caused by oversize.

Measurement of footprint loading and drive deformation would improve current understanding of stress paths that the footprint is subject to during cave establishment and maturation. An example of forecasts from a coupled flow-deformation model and comparison to measured data from the proposed monitoring project is provided in Figure 15. 


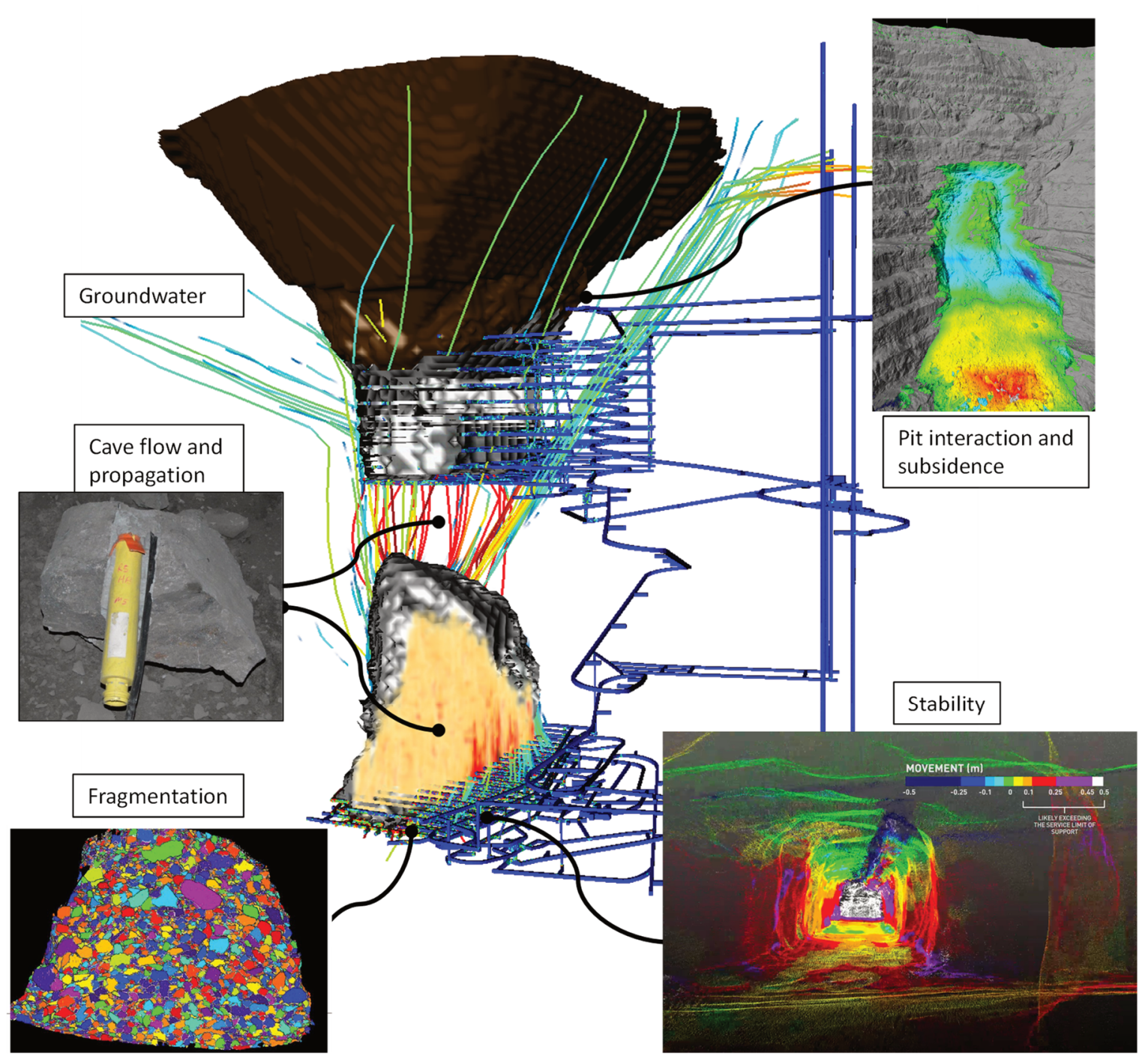

Figure 15 Example of cave monitoring and data integration to assess mine performance, including flow, recovery and stability

The second example field trial is for an SLC mine. The objective is to track cave flow using Network SMART markers to measure the extraction zone and movement growth inside a blasted ring. The Cave Tracker system was not selected due to the detection accuracy relative to the scale of the marker spacing and ring geometry and required data resolution. The purpose of the trial is to measure blast movement and the evolution of the extraction zone and movement zone within individual SLC rings. An example marker layout is provided in Figure 16. This example uses two marker rings in the blasted ring volume. Three marker rings should also be considered, similar to the marker layouts by Power (2004), and Campbell (2019). The objective of repeated trials is to quantify the effects of blast design variables on cave flow and subsequent recovery, fragmentation and blast performance. A minimum of six to 10 trial rings per blast design is recommended due to variability in recovery and flow conditions. This would also enable current SLC design guidelines to be updated and enable calibration of numerical blast models in semi-confined blasting conditions. 


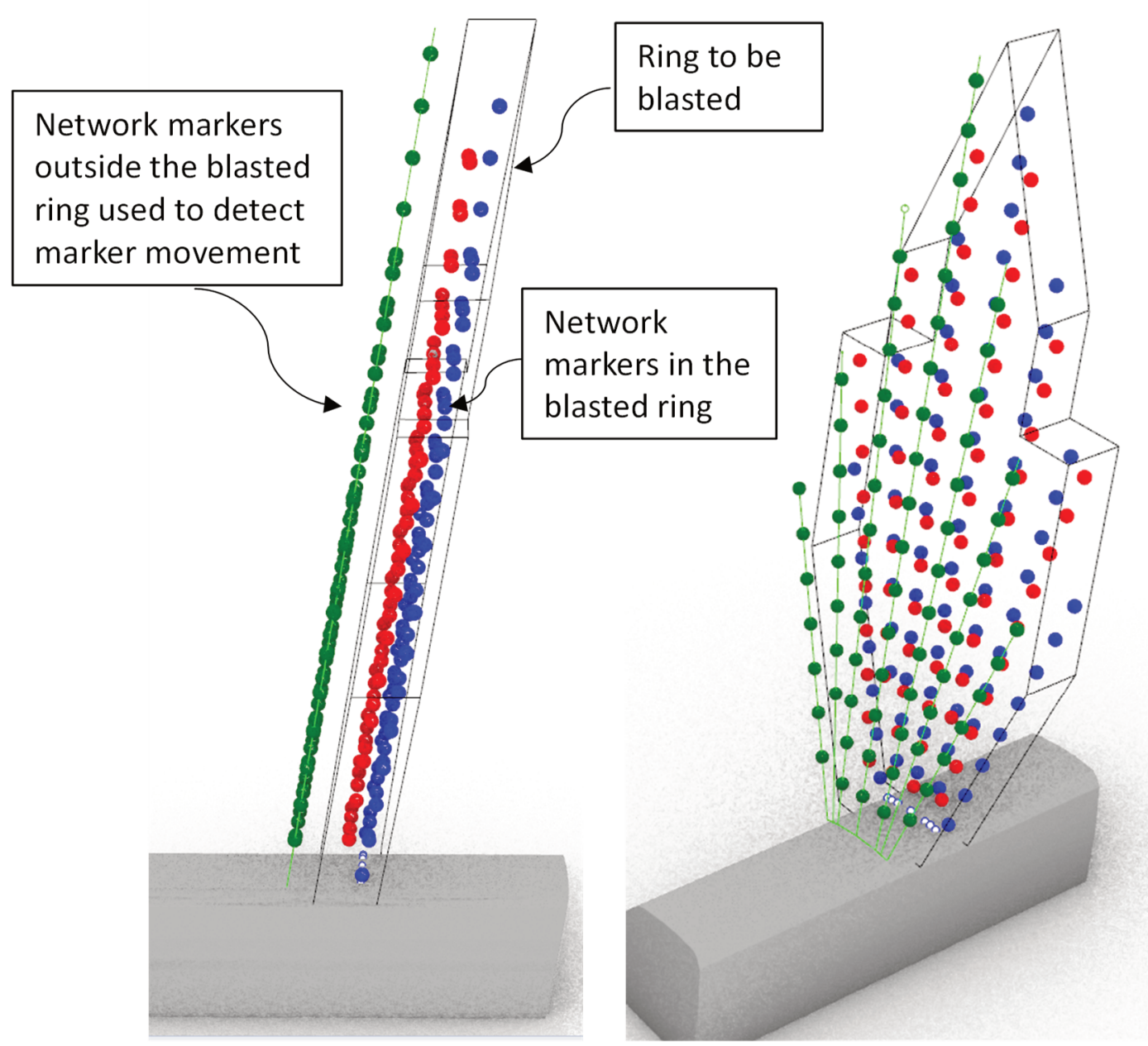

Figure 16 Schematic of Network SMART marker installation to track blast movement and evolution of the extraction and movement zones during loading (side view)

\section{Discussion}

Trials and experiments differ from routine monitoring in cave mines. Experiments generally involve targeted measurements of specific phenomena with a higher density of data collection to measure specific cave behaviour. Due to time and budget constraints and interaction with mine operations, experiments target a small area of the mine. General monitoring of a cave is likely to use a more widespread instrumentation layout and have a lower resolution. Example monitoring and experimental programmes have been proposed in this paper. However, design changes would naturally be required to suit site-specific conditions. Considerations for any experimental programme should include:

- The objective of the trial. What needs to be to be measured and how will the data be used?

- The density or spacing of measurements in space and time required to meet the objective of the trial.

- The devices available for measurement, the accuracy of the device, and installation method.

- Budget, including the cost of instrumentation, drilling, grouting, and communication cables.

- Access for installation. This is a key challenge for some caving mines, particularly those with high lift heights and limited access for drilling/installation of instruments in the cave column.

- Effects of cave propagation. Cave mines evolve over time and there is potential for infrastructure critical to monitoring to be consumed by the cave. This includes detectors for the Cave Tracker system and seismic sensors. 
- Operational and technical resourcing for installation.

- Interaction with operations. Trials should measure normal operating conditions, unless the trial is specifically designed to measure the effect of an operational change.

- Data redundancy. Sufficient devices must be installed to enable reliable measurements should some instruments malfunction or not be installed due to installation problems.

- Sensor detection and signal length. This is critical for the Cave Tracker, Network SMART marker systems, and for seismic system design.

- Data processing and analysis. Modern instrumentation is capable of collecting vast amounts of data. The design of measurement projects should keep the end in mind. This includes questions such as, how will the data be used for decision-making? How will the results be visualised and communicated? How will results from different trials be compared? An important note for trials in cave mines is that a large number of experiments or tests required to establish statistically significant datasets is (generally) not possible. One must consider how experiments testing different conditions or comparisons between different mines would be made.

- Field trials are expensive. However, the cost of field trials is minimal compared to the capital expense of a caving mine, or the cost of getting the design wrong in terms of instability, dilution or lost ore recovery.

\section{Conclusion}

This paper has provided an overview of the current state of knowledge for cave flow and existing knowledge gaps. These knowledge gaps and the implications for the mine design problem including the increasing scale of caving mines have been outlined. It is clear that caving mines cannot continue to be designed using existing guidelines and flow simulations based on idealised flow experiments and sand experiments which are now more than 25 years old.

Technological developments now enable caving mines to measure cave flow and the impact of large-scale mining dimensions on recovery. Additional trials in operating mines are critical to understanding cave flow and the implications for mine design, particularly as mines become larger and are developed at increasing depths. The final ingredients that are required are mines willing to invest in cave measurement to update existing (and outdated) design guidelines and the next generation of caving engineers willing to take on the challenge of advancing current caving knowledge.

\section{References}

Airey, LD 1965, 'The introduction of mechanised mining methods at Mufulira Copper Mines Ltd.', Proceedings of the 8th Commonwealth Mining and Metallurgical Conference, preprint 91, Australasian Institute of Mining and Metallurgy, Melbourne, pp. 16-26.

Arancibia, E, Carrasco, F, Fuentes, S \& Guarda, J 2008, 'Design of extraction layout for the Chuquicamata underground project', in $\mathrm{H}$ Schunnesson \& E Nordlund (eds), Proceedings of the 5th International Conference and Exhibition on Mass Mining (MassMin 2008), Luleå University of Technology Press, Luleå, pp. 3-14.

Beck, DA, Sharrock, G \& Capes, G 2011, 'A coupled DFE-Newtonian Cellular Automata scheme for simulation of cave initiation, propagation and induced seismicity', Proceedings of the 45th US Rock Mechanics/Geomechanics Symposium, American Rock Mechanics Association, Alexandria.

Beck, DA, Hudson, R, Wilson, AD, Duplancic, P \& Lilley, CR 2016, 'An investigation of factors affecting the long-term reliability of extraction level pillars in deep block and panel caves', Proceedings of the Seventh International Conference \& Exhibition on Mass Mining (MassMin 2016), Australasian Institute of Mining and Metallurgy, Melbourne.

Bender, J, Müller, M, Otaduy, MA, Teschner, M \& Macklin, M 2014, 'A survey on position based simulation methods in computer graphics', Computer Graphics Forum, vol. 33, no. 6, pp. 228-251.

Benter, A 2014, Characterising the Internal Composition of Rock Piles Using Ground Penetrating Radar, PhD thesis, Charles Sturt University, Bathurst.

Brunton, ID 2009, The Impact of Blasting on Sublevel Caving Flow Behaviour and Recovery, PhD thesis, The University of Queensland, Brisbane. 
Brunton, ID, Lett, JL, Sharrock, GB, Thornhill, T \& Mobilio, B 2016a, 'Full scale flow marker experiments and the Ridgeway Deeps and Cadia East cave operations', Proceedings of the Seventh International Conference \& Exhibition on Mass Mining (MassMin 2016), Australasian Institute of Mining and Metallurgy, Melbourne.

Brunton, I, Lett, J L \& Thornhill, T, 2016b, 'Fragmentation prediction and assessment at the Ridgeway Deeps and Cadia East cave operations', Proceedings of the Seventh International Conference \& Exhibition on Mass Mining (MassMin 2016), Australasian Institute of Mining and Metallurgy, Melbourne, pp. 151-160.

Brown, ET 2007, Block Caving Geomechanics, Julius Kruttschnitt Mineral Research Centre, The University of Queensland, Brisbane.

Bull, G \& Page, CH 2000, 'Sublevel caving-today's dependable low-cost 'ore factory", in G Chitombo (ed.), Proceedings of the Third International Conference \& Exhibition on Mass Mining (MassMin 2000), Instituto de Ingenieros de Chile, Santiago, pp. 537-556.

Burgio, N \& Diering, T 2008, 'Simulating irregular cave propagation using PCBC', in H Schunnesson \& E Nordlund (eds), Proceedings of the 5th International Conference and Exhibition on Mass Mining 2008, Luleå University of Technology, Luleå, pp. 1033-1042.

Campbell, AD 2018a, 'Full-scale experiments to measure the effect of crosscut height on recovery in sublevel cave mines', in Y Potvin \& J Jakubec (eds), Proceedings of the Fourth International Symposium on Block and Sublevel Caving, Australian Centre for Geomechanics, Perth, pp. 443-456.

Campbell, AD 2018b, 'Effects of blast ring burden and explosive density on fragmentation and ore recovery in sublevel cave mines', in Y Potvin \& J Jakubec (eds), Proceedings of the Fourth International Symposium on Block and Sublevel Caving, Australian Centre for Geomechanics, Perth, pp. 457-470.

Campbell, AD 2019, Full-scale Experiments and Numerical Modelling to Improve Ore Recovery in Sublevel Cave Mines, PhD thesis, The University of Queensland, Brisbane.

Campbell, AD \& Power, GR 2016, 'Increasing net present value by a third at an operating sublevel cave mine using draw strategy optimisation', Proceedings of the Seventh International Conference and Exhibition on Mass Mining (MassMin 2016), The Australasian Institute of Mining and Metallurgy, Melbourne, pp. 167-174.

Campbell, AD \& Power, GR 2017, 'Improving calibration of flow models against SLC marker trials by linking blasting effects to particle mobility', Proceedings of the 13th AusIMM Underground Operators' Conference, The Australasian Institute of Mining and Metallurgy, Melbourne, pp. 11-22.

Campbell, AD \& Thurley, MJ 2017, 'Application of laser scanning to measure fragmentation in underground mines', Transactions of the Institutions of Mining and Metallurgy, Section A: Mining Technology, vol. 126, iss. 4, pp. 240-247.

Caspar, J 1960, Model Work on Movement in Conventional SLC at Kiruna, pp. 53-103.

Castro, RL 2006, Study of the Mechanisms of Gravity Flow for Block Caving, PhD thesis, The University of Queensland, Brisbane.

Castro, R, Hekmat, A, Fuentes, M, Armijo, F \& Rodriguez, F 2016, 'FlowSim - a versatile flow simulation tool to quantify extraction and design alternatives for block caving,' Proceedings of the Seventh International Conference and Exhibition on Mass Mining (MassMin 2016), The Australasian Institute of Mining and Metallurgy, Melbourne, pp. 645-652.

Castro, R, Trueman, R \& Halim, A 2007, 'A study of isolated draw zones in block caving mines by means of a large 3D physical model', International Journal of Rock Mechanics and Mining Sciences, vol. 44, no. 6, pp. 860-870.

Cox, J 1969, 'Sublevel caving at Mulfria copper mines', Mining Magazine, vol. 20, no. 5, pp. 31-36.

Dassault Systèmes 2020, GEOVIA PCBC, computer software, Dassault Systèmes, Vélizy-Villacoublay, https://www.3ds.com/productsservices/geovia/products/pcbc/

DeGagne, DO \& McKinnon, SD 2005, 'The influence of blasting fragmentation on ore recovery in sublevel cave mines', Proceeding of The 40th US Symposium on Rock Mechanics, American Rock Mechanics Association, Alexandria.

deWolfe, C \& Ross, I 2016, 'Super caves - benefits, considerations and risks', Proceedings of the Seventh International Conference and Exhibition on Mass Mining (MassMin 2016), The Australasian Institute of Mining and Metallurgy, Melbourne, pp. 51-58.

Flores, G \& Karsulovic, A 2000, Geotechnical Guidelines for a Transition From Open Cut to Underground Mining: Benchmarking Report, report to the International Caving Study II, Julius Kruttschnitt Mineral Research Centre, Brisbane.

Free, GD 1970, Mathematical and Model Studies of the Flow of Material in the Sub-level Caving Mining Method, Master of Engineering Science thesis, The University of Queensland, Brisbane.

Gantumur, J, Godard, R, Prince, F \& Pascoe, C 2016, 'Development and evaluation processes of cave production schedules for the Resolution copper project', Proceedings Seventh International Conference and Exhibition on Mass Mining (MassMin 2016), The Australasian Institute of Mining and Metallurgy, Melbourne, pp. 59-64.

Garces, D, Viera, E, Castro, R \& Melendez, M 2016, 'Gravity flow full-scale tests at Esmerelda Mine's block-2, El Teniente', Proceedings of the Seventh International Conference and Exhibition on Mass Mining (MassMin 2016), The Australasian Institute of Mining and Metallurgy, Melbourne, pp. 349-358.

Gardner, GC 1966, 'The region of flow when discharging granulai materials from bin-hopper systems', Chemical Engineering Science, vol. 21, pp. 261-273.

Gustafsson, P 1998, Waste Rock Content Variations During Gravity Flow in Sublevel Caving: Analysis of Full-scale Experiments and Numerical Simulations, PhD thesis, Luleå University of Technology, Luleå.

Halim, A 2006, Study of the Influence of Interactive Draw upon Drawpoint Spacing in Block and Sublevel Caving Mines, PhD thesis, The University of Queensland, Brisbane.

Hancock, W 2013, Gravity Flow of Rock in Caving Mines: Numerical Modelling of Isolated, Interactive and Non-ideal Draw, PhD thesis, The University of Queensland, Brisbane.

Hebert, Y \& Sharrock, G 2018, 'Three-dimensional simulation of cave initiation, propagation and surface subsidence using a coupled finite difference-cellular automata solution', in Y Potvin \& J Jakubec (eds), Proceedings of the Fourth International Symposium on Block and Sublevel Caving, Australian Centre for Geomechanics, Perth, pp. 151-166. 
Heslop, G \& Laubscher, D 1981, 'Draw control in caving operations on southern African chrysotile asbestos mines', in DR Stewart (ed.), Design and Operation of Caving and Sublevel Stoping Mines, Society of Mining Engineers, New York, pp. 715-728.

Hocking, R, Balog, G, Ormerod, T \& Pearce, H 2018, 'Early cave management at the Carrapateena sublevel cave', in Y Potvin \& J Jakubec (eds), Proceedings of the Fourth International Symposium on Block and Sublevel Caving, Australian Centre for Geomechanics, Perth, pp. 421-432.

Hollins, B \& Tucker, J 2004, 'Draw point analysis using a marker trial at the Perseverance Nickel Mine, Leinster, Western Australia', in A Karzulovic \& MA Alafaro (eds), Proceedings of the Fourth International Conference and Exhibition on Mass Mining (MassMin 2004), Instituto de Ingenieros de Chile, Santiago, pp. 498-502.

Janelid, I 1972, 'Study of the gravity flow process in sublevel caving', Proceedings of the International Sublevel Caving Symposium, Atlas Copco, London, pp. 1-23.

Janelid, I \& Kvapil, R 1966, 'Sublevel caving', International Journal Rock Mechanics and Mining Science, vol. 3, pp. 129-153.

Jones, E \& Beck, D 2017, 'The use of 3D laser scanning for deformation monitoring in underground mines', Proceedings of the 13th AusIMM Underground Operators' Conference, The Australasian Institute of Mining and Metallurgy, Melbourne, pp. 267-270.

Just, GD 1981, 'The significance of material flow in mine design and production', in DR Stewart (ed.), Design and Operation of Caving and Sublevel Stoping Mines, Society of Mining Engineers, New York, pp. 715-728.

Kloss, C, Hager, A, Amberger, S \& Pirker S 2012, 'Models, algorithms and validation for opensource DEM and CFD-DEM', Progress in Computational Fluid Dynamics, An International Journal, vol. 12, no. 2/3, pp. 140-152.

Kvapil, R 1965, 'Gravity flow of granular materials in hoppers and bins-Part 2 Coarse material', International Journal of Rock Mechanics and Mining Sciences, vol. 2, no. 3, pp. 277-292.

Kvapil, R 1992, 'Sublevel caving', SME Mining Engineering Handbook, Society for Mining, Metallurgy \& Exploration, Englewood, pp. 1789-1814.

Laubscher, DH 1994, 'Cave mining - the state of the art', The Journal of The South African Institute of Mining and Metallurgy, vol. 94, iss. 10, pp. 279-293.

Laubscher, DH 2000, A Practical Manual on Block Caving, Julius Kruttschnitt Mineral Research Centre and Itasca Consulting Group Inc., Brisbane.

Laubscher, DH, Guest, A \& Jakubec, J 2017, Guidelines on Caving Mining Methods - The Underlying Concepts, W.H. Bryan Mining \& Geology Research Centre, Brisbane.

Lorig, LJ \& Cundall, PA 2000, A Rapid Gravity Flow Simulator, Julius Kruttschnitt Mineral Research Centre and Itasca Consulting Group Inc., Brisbane.

Marano, G 1980, 'The interaction between adjoining draw points in free flowing materials and its application to mining', Chamber of Mines Journal, Zimbabwe, May, pp. 25-32.

Macklin, M, Müller, M \& Chentanez, N 2016, 'XPBD: position-based simulation of compliant constrained dynamics', Proceedings of the 9th International Conference on Motion in Games, Association for Computing Machinery, New York.

Macklin, M, Müller, M, Nattapong, C \& Tae-Yong, K 2014, 'Unified particle physics for real-time applications', ACM Transactions on Graphics, vol. 33, no. 4.

McCormick, R 1968, 'How wide does a drawpoint draw?', Engineering and Mining Journal, June, pp. 106-116.

McDonald, A 2004, Sub-level Cave Draw Marker Study Results - Report 1, Perseverance Nickel Mine.

Minchinton, A \& Dare-Bryan, P 2005, 'The application of computer modelling for blasting and flow in sublevel caving operations', Proceedings of the Ninth Underground Operators' Conference, The Australasian Institute of Mining and Metallurgy, Melbourne, pp. 65-74.

Müller, M 2006, 'Position based dynamics', in C Mendoza \& I Navazo (eds), Proceedings of the 3rd Workshop in Virtual Reality Interactions and Physical Simulation "VRIPHYS", Eurographics Association, Geneve.

Panczakiewicz, T 1977, Optimization of the Sublevel Caving Mining Method Investigated by Physical Models, MSc thesis, The University of Melbourne, Melbourne.

Peters, D 1984, 'Physical modelling of the draw behaviour of broken rock in caving', Quarterly of the Colorado School of Mines, vol. 79, no. 1.

Pierce, ME 2010, A Model for Gravity Flow of Fragmented Rock in Block Caving Mines, PhD thesis, The University of Queensland, Brisbane.

Pierce, ME \& Hakan, S 2004, 'PFC3D modelling of flow behaviour in sublevel caving', in A Karzulovic \& A Alfaro (eds), Proceedings of the Fourth International Conference and Exhibition on Mass Mining (MassMin 2004), Instituto de Ingenieros de Chile, Santiago, pp. 201-214.

Power, GR 2004, Modelling Granular Flow in Caving Mines: Large Scale Physical Modelling and Full Scale Experiments, PhD thesis, The University of Queensland, Brisbane.

Power G 2012, 'Optimizing caving recovery using comparative draw planning strategies and PGCA flow modelling software', Proceedings of the 6th International Conference \& Exhibition on Mass Mining (MassMin 2012), Canadian Institute of Mining, Metallurgy and Petroleum, Sudbury.

Power, G \& Campbell, AD 2016, 'Modelling of real-time marker data to improve operational recovery in sublevel caving mines', Proceedings of the Seventh International Conference and Exhibition on Mass Mining (MassMin 2016), Canadian Institute of Mining, Metallurgy and Petroleum, Sudbury, pp. 105-110.

Quinteiro, CR, Larsson, L \& Hustrulid, WA 2001, 'Theory and practice of very large scale sublevel caving', in WA Hustrulid \& RL Bullocks (eds), Underground Mining Methods - Engineering Fundamentals and International Case Studies, Society for Mining, Metallurgy \& Exploration, Englewood, pp. 381-384.

Redaelli, L 1963, 'Sub-level caving at Koskullskulle', Mine and Quarry Engineering, June, pp. 261-264. 
Richardson, MP 1981, 'Area of draw influence and drawpoint spacing for block caving mines', in DR Stewart (ed.), Design and Operation of Caving and Sublevel Stoping Mines, Society of Mining Engineers, New York, pp. 149-156.

Sandstrom, P 1972, 'Application and optimisation of sublevel caving techniques', Engineering and Mining Journal, June, pp. $112-125$.

Sellden, H \& Pierce, M 2004, 'PFC3D modelling of flow behaviour in sublevel caving', Proceedings of the Fourth International Conference and Exhibition on Mass Mining (MassMin 2004), Instituto de Ingenieros de Chile, Santiago, pp. $201-214$.

Sharrock, G \& Hashim, M 2009, 'Disturbed gravity flow in block caving', Proceedings of the 3rd US Rock Mechanics Symposium and 4th US-Canada Rock Mechanics Symposium, American Rock Mechanics Association, Alexandria.

Stazhevskii, SB 1996, 'Features of flow of broken rock in extraction of ores with sublevel caving', Journal of Mining Science, vol. 32 , no. 5, pp. 403-416.

Steffan, S \& Kuiper, P 2012 'Maximising ore recovery and the implication for cave monitoring and management practices - application of the smart marker system in block and sub-level mines', Proceedings of the 6th International Conference \& Exhibition on Mass Mining (MassMin 2012), Canadian Institute of Mining, Metallurgy and Petroleum, Sudbury.

Stegman, C, van As, A \& Peebles, E 2018, 'Past learnings focus innovative solutions to future cave mining', in Y Potvin \& J Jakubec (eds), Proceedings of the Fourth International Symposium on Block and Sublevel Caving, Australian Centre for Geomechanics, Perth, pp. 37-42.

Van As, A \& Van Hout, GJ 2008, 'Implications of widely spaced drawpoints', in H Schunnesson \& E Nordlung (eds), Proceedings of the 5th International Conference and Exhibition on Mass Mining (MassMin 2008), Luleå University of Technology, Luleå, pp. $147-154$.

Whiteman, D 2010, 'The SMART Marker System - a new tool for measuring underground ore body flow in block and sub-level mines', in Y Potvin (ed.), Proceedings of the Second International Symposium on Block and Sublevel Caving, Australian Centre for Geomechanics, Perth, pp. 603-621.

Whiteman, D, Talu, S, Wilson, M, Watt, G, Van As, A \& Kuiper, P 2016, 'Cave Tracker flow monitoring system installation at Argyle Diamond Mine', Proceedings of the Seventh International Conference and Exhibition on Mass Mining (MassMin 2016), pp. 479-488, The Australasian Institute of Mining and Metallurgy, Melbourne. 
